https://helda.helsinki.fi

\title{
Vitamin C and plasma cholesterol
}

\section{Hemilä, Harri}

1992

Hemilä , H 1992 , ' Vitamin C and plasma cholesterol ' , Critical Reviews in Food Science and Nutrition , vol. 32 , no. 1 , pp. 33-57 . https://doi.org/10.1080/10408399209527579

http://hdl.handle.net/10138/321504

https://doi.org/10.1080/10408399209527579

publishedVersion

Downloaded from Helda, University of Helsinki institutional repository.

This is an electronic reprint of the original article.

This reprint may differ from the original in pagination and typographic detail.

Please cite the original version. 


\title{
Vitamin C and Plasma Cholesterol
}

\author{
Harri Hemilä \\ Department of Public Health, University of Helsinki, Haartmaninkatu 3, 00290 Helsinki, Finland
}

KEY WORDS: ascorbic acid, cholesterol, lipoproteins, triglycerides, atherosclerosis.

\section{INTRODUCTION}

There has been a long-lasting controversy about whether vitamin $\mathrm{C}$ has any significant effect on plasma cholesterol levels in human beings. Some early Russian studies suggested that vitamin C may decrease elevated cholesterol levels, and so the vitamin was used to some extent in the treatment of hypercholesterolemia (for review see Reference 1). However, the studies were not well controlled, and duplications have yielded conflicting results. Nevertheless, animal studies have consistently found that vitamin $\mathrm{C}$ has substantial effects on cholesterol metabolism.

The purpose of this review is to analyze the published intervention studies in order to identify the factors that may have resulted in the discordance in the results. Several of the studies have used subjects with initially low cholesterol levels. Such studies do not test the hypothesis that a low level of the vitamin may decrease the rate of cholesterol catabolism, and thereby enhance hypercholesterolemia in some people. Accordingly, studies with hypercholesterolemic subjects are more relevant for testing this hypothesis. Most of the studies in the latter group have reported a significant decrease in the cholesterol level with vitamin $\mathrm{C}$ supplementation. Furthermore, such results indicate that in certain people low vitamin $\mathrm{C}$ status may be one of the factors that lead to the elevation of cholesterol levels.

\section{CHOLESTEROL METABOLISM}

\section{A. Guinea Pigs}

The role of vitamin $\mathrm{C}$ in cholesterol metabolism has been studied extensively in guinea pigs (for review see References 2 through 4). Guinea pigs are the experimental animals of choice for physiological studies dealing with vitamin $\mathrm{C}$ because they do not synthesize the vitamin themselves, unlike most other mammals. Complete lack of vitamin $C$ causes scurvy, a complicated pathological state characterized by anorexia, weight loss, hemorrhages, and finally death. In guinea pigs, a long-term marginal vitamin $\mathrm{C}$ intake also results in low levels of the vitamin in the body. ${ }^{3,5}$ Marginal vitamin $\mathrm{C}$ deficiency is a relevant model when studying the effects of low vitamin levels, since it is a stable physiological state and may allow more reasonable extrapolation in regard to humans with low levels of vitamin intake.

In guinea pigs, a marginal vitamin $\mathrm{C}$ deficiency increases cholesterol levels in plasma and various tissues. ${ }^{6-31}$ Synthesis of bile acids is decreased and the composition of bile is changed in marginal ${ }^{24-33}$ and in acute ${ }^{34-36}$ deficiency. Cholesterol-containing gallstones may also be formed in vitamin-deficient guinea pigs. ${ }^{3,32,33}$ Even though the cholesterol levels are elevated when the feed is normal except for the low level of the vitamin, the increase is more pronounced when vitamin-

$1040-8398 / 92 / \$ .50$

(C) 1992 by CRC Press, Inc. 
deficient guinea pigs are fed an atherogenic diet (cholesterol, coconut oil). 17,18,20,21,37-39

The increase in cholesterol levels by vitamin $\mathrm{C}$ deficiency is not caused by a significant increase in the rate of cholesterol synthesis. Cholesterol synthesis is not affected or may be decreased by vitamin deficiency ${ }^{6,40-42}$ (Figure 1). 3-Hydroxy-3-methylglutaryl coenzyme A (HMG$\mathrm{CoA}$ ) reductase is the rate-limiting enzyme in cholesterol synthesis. The activity of HMG-CoA reductase, in vivo, is decreased or unaffected in guinea pigs that have been fed low amounts of the vitamin. ${ }^{11,14,43}$ High concentrations of vitamin $\mathrm{C}$ inhibit the activity of HMG-CoA reductase in vitro,${ }^{44}$ but it is not clear whether this effect is physiologically significant. Finally, vitamin C deficiency does not increase the absorption of cholesterol from the intestines, but rather the absorption appears to decrease. ${ }^{3,45}$

Cholesterol $7 \alpha$-hydroxylase is the rate-limiting enzyme ${ }^{46}$ in bile acid synthesis (i.e., cholesterol catabolism). In vivo, the activity of $7 \alpha-$ hydroxylase is considerably decreased $(-30$ to $-80 \%$ ) in vitamin $\mathrm{C}$ deficiency. ${ }^{11,15,30,35,47,48}$ Consistently, vitamin $\mathrm{C}$ deficiency does not affect the catabolism of $7 \alpha$-hydroxycholesterol, which is the end product of cholesterol $7 \alpha$-hydroxylase. ${ }^{9,49}$ The effect on $7 \alpha$-hydroxylase appears to be the major mechanism whereby vitamin $\mathrm{C}$ affects cholesterol levels and bile acid synthesis. The major effect of the vitamin on cholesterol $7 \alpha$-hydroxylase is indirect: vitamin C is not a cofactor for the enzyme and the vitamin does not markedly affect $7 \alpha$-hydroxylase activity in vitro. ${ }^{47,50}$ However, the precise mechanism of the effect has not yet been defined. ${ }^{4}$

When guinea pigs are fed very large quantities of vitamin $C$, no reduction is observed in the cholesterol levels when compared with animals fed a normal diet; ${ }^{13,18,22,51}$ instead, cholesterol levels may actually increase. ${ }^{11,19,23,27,30,31} \mathrm{In}$ fact, the activity of cholesterol $7 \alpha$-hydroxylase is also decreased by very high amounts of the vitamin. ${ }^{11,15,30,48}$ However, when guinea pigs are fed an atherogenic diet, high doses of the vitamin may lead to a decrease in the cholesterol levels. $7,15,16,18,51,52$

The studies with marginally deficient guinea pigs have very consistently found an increase in

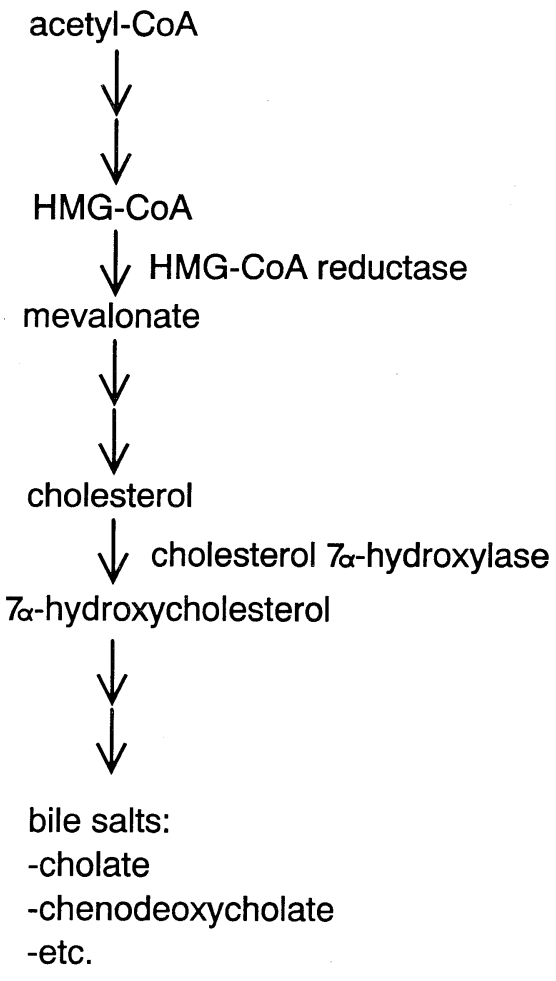

FIGURE 1. Schematic presentation of cholesterol metabolism. HMG-CoA reductase is the rate-limiting enzyme in cholesterol synthesis, and cholesterol $7 \alpha-$ hydroxylase is the rate-limiting enzyme in cholesterol catabolism. Two arrows are used to indicate several consecutive enzymatic steps. HMG-CoA: 3-hydroxy-3methylglutaryl CoA.

cholesterol levels in various tissues, but the studies with acute deficiency, scurvy, have yielded ambiguous results. ${ }^{2,3}$ In acute deficiency, with no dietary vitamin $C$, cholesterol levels have been reported to decrease $\mathrm{e}^{6,16,35,53}$ or increase $\mathrm{i}^{37-39,54-58}$ in plasma, and decrease $e^{6,35,37}$ or increase ${ }^{16,53,57,59}$ in the liver. Apparently, the variable effects of acute deficiency on cholesterol levels may depend on coincident effects of the vitamin on the synthesis and catabolism of cholesterol. Interestingly, Willis ${ }^{60}$ observed in an early report that acute vitamin $\mathrm{C}$ deficiency caused the formation of lipid deposits in the aorta of scorbutic guinea pigs, but the deposits disappeared within a few days of the animals being fed the vitamin. However, advanced atherosclerotic type lesions were considerably more resistant to resorption. 


\section{B. Rabbits, Rats, and Pigs}

The effect of vitamin $\mathrm{C}$ on cholesterol metabolism has been studied also in rabbits, rats, and pigs that synthesize the vitamin themselves. Administration of cholesterol to these species increases cholesterol levels in plasma and tissues, but the elevation is significantly smaller when vitamin $\mathrm{C}$ is supplemented. ${ }^{61-69}$ One study with rabbits found only an insignificant decrease in the cholesterol levels when the vitamin was supplemented..$^{70}$ However, much larger quantities of cholesterol were fed compared with another, more thorough study, ${ }^{64}$ and thus any modest effects produced by the vitamin could be overshadowed. It has also been reported that extra vitamin $\mathrm{C}$, in the absence of dietary cholesterol, decreases the cholesterol level in the serum, liver, and aorta of rats, ${ }^{71,72}$ although one study found no effect. ${ }^{73}$ Since rats synthesize vitamin $\mathrm{C}$ by themselves, any effect of extra vitamin $\mathrm{C}$ may depend on several experimental variables, and a discrepancy in the results is not surprising.

Furthermore, the role of vitamin $\mathrm{C}$ has been studied in mutant rats that were unable to synthesize this vitamin. Vitamin deficiency had only minor effects on cholesterol metabolism in these rats when a normal diet is administered. However, when they were fed cholesterol, vitamin deficiency resulted in the accumulation of cholesterol in the plasma and liver, a lower activity of cholesterol $7 \alpha$-hydroxylase, and lower excretion of fecal bile acids, when compared with mutant rats fed normal amounts of the vitamin, ${ }^{74-76}$ or to normal rats. ${ }^{77}$

\section{Effect of Cholesterol on Vitamin C Metabolism}

Administration of cholesterol to guinea pigs decreases the tissue-levels of vitamin $C, 7,18,20,21,37,78$ which indicates increased consumption of the vitamin. Increased catabolism of vitamin C was directly observed in one study, ${ }^{79}$ and it has also been reported that the feeding of cholesterol increases the amount of vitamin C required for normal growth. ${ }^{7,79}$

It seems reasonable to conclude that under normal conditions rats and rabbits synthesize vi- tamin $\mathrm{C}$ in amounts close to the optimal levels. ${ }^{80,81}$ However, the feeding of cholesterol could increase the optimal amount of the vitamin, and thus affect the rate of its synthesis. For example, several drugs cause a dramatic increase in the synthesis of vitamin $\mathrm{C}$ in rats. ${ }^{82,83} \mathrm{In}$ one study, the administration of cholesterol to rats and rabbits increased the level of vitamin $\mathrm{C}$ in several tissues, ${ }^{78}$ and this was presumed to be due to an increase in vitamin synthesis. In another experiment, cholesterol-feeding led to a decrease in vitamin levels in the tissues of rats, ${ }^{84}$ with no effect being found on the rate of vitamin synthesis, although the rate of vitamin $\mathrm{C}$ catabolism was increased. However, among other experimental differences, an amount of cholesterol 2.5 times as high was used in the latter experiment, and such differences could possibly explain the discrepancy in the vitamin levels. Apparently, the rate of vitamin $\mathrm{C}$ synthesis is not increased enough in the animals that synthesize the vitamin when they are fed an atherogenic diet because supplemental vitamin causes a decrease in the cholesterol levels. ${ }^{61-69}$ Novitskii $^{85}$ observed that in two groups of rabbits that responded to dietary cholesterol by either increasing or maintaining plasma cholesterol levels there were respective differences in vitamin $\mathrm{C}$ metabolism, and he speculated that the differences in the effects on dietary cholesterol could be due to the differences in vitamin $\mathrm{C}$ metabolism.

\section{Lipoproteins and Lipid Oxidation}

Vitamin C deficiency decreases HDL-cholesterol levels in guinea pigs, ${ }^{17,20,21,38,39,56}$ and vitamin supplementation increases the HDL-cholesterol levels in guinea pigs fed an atherogenic diet. ${ }^{51}$ When vitamin-dependent rats were put on a vitamin C-deficient diet, their plasma HDLcholesterol level became lower than in mutant rats that were given the vitamin, ${ }^{74,76}$ or in normal rats. ${ }^{77}$ The mechanism whereby vitamin $\mathrm{C}$ could affect the level of HDL-cholesterol is not clear, but it is noteworthy that vitamin $\mathrm{C}$ seems to increase the activity of lipoprotein lipase (see Sections III and V.C), which in turn appears to participate in the regulation of HDL metabolism..$^{86,87}$ 
In guinea pigs, vitamin $\mathrm{C}$ deficiency decreases the rate of catabolism of LDL-cholesterol, ${ }^{88}$ and increases the level of LDL-cholesterol in plasma. ${ }^{20,37,38,56} \mathrm{High}$ levels of the vitamin significantly decrease LDL cholesterol levels in guinea pigs that are fed an atherogenic diet. ${ }^{51}$ In one study using vitamin-dependent rats, LDLcholesterol levels were about three times higher in the group receiving a vitamin-deficient diet than in the control group. ${ }^{89}$ Furthermore, vitamin $\mathrm{C}$ increases the number of LDL receptors in cultured arterial smooth muscle cells. ${ }^{90}$ It has also been suggested that the vitamin plays an important role in the metabolism of lipoprotein(a), which has been linked with atherosclerosis. ${ }^{91-93}$

Lipid oxidation has emerged as a potential factor in the etiology of atherosclerosis. ${ }^{94,95}$ Vitamin $\mathrm{C}$ is the major water-soluble antioxidant, ${ }^{96-99}$ and it may decrease lipid oxidation, either directly or indirectly, by regenerating vitamin $\mathrm{E}$, the major lipid soluble antioxidant. ${ }^{99-102}$ It has been reported recently that vitamin $\mathrm{C}$ may protect lowdensity lipoproteins ${ }^{103-105}$ and plasma lipids ${ }^{96,97}$ against free radical-mediated oxidation. Previous data have indicated that vitamin $\mathrm{C}$ deficiency increases $\mathrm{CCl}_{4}$-induced lipid oxidation in vivo in guinea pigs, ${ }^{106}$ and that vitamin $\mathrm{C}$ supplementation decreases lipid peroxidation in vivo in rats that have an iron overload. ${ }^{107}$ Furthermore, it has been reported that people with low vitamin $\mathrm{C}$ levels have higher amounts of lipid peroxides in plasma than do people with high vitamin levels. ${ }^{108}$ Accordingly, vitamin $\mathrm{C}$ could also affect cholesterol metabolism through the antioxidant effect.

Because of the similarity among mammals at the biochemical level, vitamin $\mathrm{C}$ may play a role in the cholesterol metabolism of human beings also. However, there may be large quantitative differences between the metabolism of different species, and, therefore, studies in man are required in order to estimate whether vitamin $\mathrm{C}$ affects cholesterol metabolism in man to a degree that is quantitatively significant.

\section{TRIGLYCERIDE METABOLISM}

Vitamin $\mathrm{C}$ appears to affect triglyceride metabolism. Several studies have reported an increase in plasma triglyceride levels in guinea pigs that have been administered a diet containing a minimal amount of vitamin C. ${ }^{16-23,28,35,37-39,52,109-112}$ When guinea pigs, ${ }^{16,18,51}$ hamsters, ${ }^{3}$ rats, or rabbits ${ }^{64,69}$ are administered extra vitamin C, the increase in triglyceride levels caused by an atherogenic diet is partially prevented. Also, a statistically significant decrease in plasma triglyceride level was found when vitamin $\mathrm{C}$ was given to rats that were fed on an otherwise normal diet. ${ }^{71}$ Finally, low vitamin C levels have been associated with increased triglyceride levels in baboons ${ }^{113}$ and rhesus monkeys. ${ }^{14,115}$

Sokoloff et al. ${ }^{64}$ suggested that the lowering of triglyceride levels by vitamin $C$ could be due to an effect on lipoprotein lipase, which is the major enzyme that degrades plasma triglycerides. ${ }^{116}$ They found that concomitantly with the elevation of triglyceride levels, lipoprotein lipase activity steadily decreased in rats and rabbits that were fed cholesterol. Extra vitamin C completely prevented the decrease in lipoprotein lipase activity and partially prevented the increase in triglyceride levels. ${ }^{64}$ Furthermore, in guinea pigs vitamin $\mathrm{C}$ deficiency decreased, ${ }^{37,110}$ and in baboons vitamin $\mathrm{C}$ supplementation increased ${ }^{117} \mathrm{li}^{\mathrm{i}}$ poprotein lipase activity. So far, the mechanism whereby vitamin $\mathrm{C}$ could affect the activity of lipoprotein lipase has not been determined.

Vitamin $\mathrm{C}$ also affects fatty acid metabolism by participating in the synthesis of carnitine. ${ }^{18,119}$ Carnitine plays a crucial role in the transport of long-chain fatty acids into mitochondria where $\beta$-oxidation takes place. ${ }^{19,120}$ Carnitine deficiency has been suspected to play a role in some diseases including hyperlipidemia. ${ }^{121}$ In some studies with human subjects, administration of carnitine has led to decreased triglyceride levels. ${ }^{121}$ In scorbutic guinea pigs, the carnitine levels of various tissues decrease ${ }^{122-126}$ and, moreover, administration of carnitine to scorbutic guinea pigs slowed down weight loss and increased the survival time by $10 \% .{ }^{127}$ Marginal vitamin $\mathrm{C}$ deficiency also decreases carnitine levels. ${ }^{22,112}$ 


\section{PHYSIOLOGICAL STUDIES IN MAN AND PRIMATES}

\section{A. Acute Scurvy}

In scorbutic human beings plasma cholesterol levels are reduced, apparently due to a decrease in synthesis and intestinal absorption. ${ }^{128-130}$ Administration of vitamin $\mathrm{C}$ to scorbutic people caused an increase in cholesterol levels. ${ }^{128,129}$ Still, acute scurvy may affect cardiac functions: some scorbutic patients have ECG-abnormalities ${ }^{131-133}$ and cardiomegaly, ${ }^{134}$ which disappear after vitamin treatment. It has also been reported that atherosclerotic changes are reversed in certain subjects by vitamin $C$ supplementation, but the initial vitamin status of the subjects was not determined. ${ }^{135}$

The effects of a vitamin C-deficient diet on cholesterol metabolism has been studied in monkeys. In baboons ${ }^{113}$ and rhesus monkeys ${ }^{114,136}$ plasma cholesterol level decreased, but in marmoset monkeys it increased. ${ }^{137}$ Liver homogenates from scorbutic baboons incorporated $\left[{ }^{14} \mathrm{C}\right]-$ acetate into cholesterol at a reduced rate. ${ }^{138,139}$ It should be noted that these studies do not test the effect of long-term marginal vitamin $\mathrm{C}$ deficiency. In guinea pigs, acute vitamin $\mathrm{C}$ deficiency has caused variable effects, but a longterm marginal deficiency has consistently increased cholesterol levels in plasma and tissues (see Section II.A).

\section{B. Supplementation and Depletion in Man}

Two studies have been conducted to examine the effects of vitamin $C$ supplementation (1 to 5 $\mathrm{g} / \mathrm{d}$ ) on bile acid metabolism in healthy, wellnourished humans. ${ }^{140,141}$ Vitamin supplementation had no clear effects on bile acid levels. On the other hand, results from animal studies suggest that the most significant effects should be expected when a long-term marginal deficiency of vitamin C is compared with good vitamin status, and not by supplementation of subjects that have initially good vitamin status (see Section II.A).

The effect of dietary restriction of vitamin $\mathrm{C}$ was examined in one study, with no consistent effects being observed in plasma cholesterol, biliary lipid composition, or bile acid synthesis rate. ${ }^{142}$ However, the study lasted for quite a short period: the vitamin $\mathrm{C}$ level in plasma barely reached low levels $(10 \mu M)$ during the test period of 2 months. In contrast, the studies with guinea pigs that had reached low vitamin $\mathrm{C}$ levels before the start of the trial usually lasted for 2 to 5 months. ${ }^{6-31}$ Also, four out of five subjects in the study $^{142}$ had a high initial vitamin $C$ level (over $45 \mu M)$. Quite a long depletion period may be required to observe whether low vitamin levels have noticeable effects in subjects with such high initial vitamin levels. Interestingly, vitamin depletion did cause a reduction in bile acid synthesis in the subject who had the lowest initial vitamin level $(27 \mu M)$, and the synthesis returned to base line levels when the vitamin was readministered to him. ${ }^{142}$

Even if vitamin $\mathrm{C}$ affects cholesterol metabolism in humans, it seems obvious that not all people respond to low vitamin levels by developing an elevated cholesterol level. In general, the correlations between vitamin $\mathrm{C}$ and cholesterol levels are quite low, even though the negative correlation has reached statistical significance in several studies (see Section VI.A). Still, it is possible that in certain subgroups low vitamin C level tends to elevate cholesterol level, which could, in turn, be lowered through vitamin C supplementation.

\section{INTERVENTION STUDIES}

The effect of supplemental vitamin $\mathrm{C}$ on plasma cholesterol has been analyzed in a number of intervention studies (Table 1). The results are quite conflicting, yet a moderately consistent picture may be obtained when taking into account some of the apparent differences in the studies. 
TABLE 1

Vitamin C and Plasma Cholesterol: Intervention Studies

\begin{tabular}{|c|c|c|c|c|c|c|c|}
\hline \multirow[b]{2}{*}{ dy } & \multirow{2}{*}{$\begin{array}{c}\text { No. subjects; } \\
\text { age, mean/ } \\
\text { range }(y)^{\mathrm{a}}\end{array}$} & \multirow{2}{*}{$\begin{array}{l}\text { Vitamin } \\
\text { dose } \\
(\mathrm{g} / \mathrm{d})\end{array}$} & \multirow{2}{*}{$\begin{array}{l}\text { Duration } \\
\text { of study } \\
\text { (weeks) }\end{array}$} & \multirow[b]{2}{*}{$\begin{array}{l}\text { Control } \\
\text { group }\end{array}$} & \multicolumn{2}{|c|}{ Pretreatment } & \multirow{2}{*}{$\begin{array}{c}\text { Change in } \\
\text { cholesterol } \\
\text { (\%) }\end{array}$} \\
\hline & & & & & $\underset{(\mu M)}{\text { Vitamin } C}$ & $\begin{array}{c}\text { Cholesterol } \\
(\mathrm{m} M)\end{array}$ & \\
\hline
\end{tabular}

Ref.

Low initial plasma cholesterol (average below $5 \mathrm{mM}$ )

Anderson et al. 1972

Crawford et al. 1975

Menne et al. 1975

Johnson 1981

Joshi et al. 1981

Khan 1981

Buzzard et al. 1982
Horsey et al. 1981

$\begin{array}{llr}41,21 & 1 & 14 \\ 18,25 & 1 & 12 \\ 122,18-25 & 1 & 16 \\ 14,82 & 1 & 6 \\ 9,20-40 & 1 & 6 \\ 27,17-20 & 2 & 3 \\ 13,21-28 & 1 & 4 \\ 20,21-35 & 2 & 6 \\ 20,21-35 & 2^{\text {d }} & \end{array}$

Average, group 1:

$\begin{array}{ll}\mathrm{P} & - \\ \mathrm{C} & - \\ \mathrm{P} & 74 \\ -\mathrm{P} & - \\ - & 74 \\ - & - \\ \mathrm{P} & 60 \\ & 78 \\ & 84\end{array}$

84

$\begin{array}{lll}4.8 & +5^{\mathrm{c}} & 143 \\ 4.9 & +7(+4) & 144 \\ 4.5 & +9(+5) & 145 \\ 4.6 & +6 & 146 \\ 4.3 & +5(+6) & 147 \\ 4.2 & +14 & 148 \\ 4.6 & 0 & 149 \\ 4.1 & 0(+4) & 150 \\ 4.1 & +8(+7) & \\ & & \\ 4.4 & +6.1\end{array}$

Medium initial plasma cholesterol (average 5-6.5 $\mathrm{mM}$ ):

Sokoloff et al. 1967

Spittle 1971

Hanck 1973

Crawford et al. 1975

Ginter et al. 1977

Kothari and Jain 1977

Vijayakumar 1980

Horsey et al. 1981

Fidanza et al. 1982

Dobson et al. 1984

Koh 1984

Burr et al. 1985

Erden et al. 1985

Aro et al. 1988

O'Brien 1988

Salonen et al. 1991

Average, group 2

$\begin{array}{lllll}40,17-36 & 2 & 22-26 & P & - \\ 28,44-70 & 2 & 34 & & \\ 58,- & 1 & 6 & - & - \\ 25,54^{\mathrm{e}} & & & & \\ 10,25-45 & 4 & 3 & - & 58 \\ 16,25 & 1 & 12 & \mathrm{C} & - \\ 82,64 & 1 & 12 & - & 23 \\ 20,20-30 & 1 & 4 & \mathrm{C} & 43 \\ 30,30-45 & 3 & 1 & - & - \\ 11,82^{\mathrm{e}} & 1 & 6 & - & - \\ 20,44-79 & 3 & 3 & - & - \\ 19,29 & 1 & 26 & \mathrm{C} & 48 \\ 23,>35 & 1 & 12 & - & 90 \\ 130,65-74 & 0.15 & 6 & \mathrm{C} & 9 \\ 25,21 & 2 & 8 & - & - \\ 27,81 & 2 & 6 & \text { DB } & 24 \\ & 0.2 & & & \\ 20,45 & 1.5 & 12 & \mathrm{C} & 56 \\ 39,54 & 0.6^{\mathrm{f}} & 20 & \text { DB } & 28\end{array}$

High initial plasma cholesterol (average over $6.5 \mathrm{mM}$ ):

Vitamin C level was determined

Ginter et al. 1970

Peterson et al. 1975

Ginter et al. 1977

Kothari and Jain 1977

Ginter et al. 1978

Ginter et al. 1979

$\begin{array}{llr}42,>40 & 0.3 & 7 \\ 13,9 & & \\ 9,46 & 4 & 8 \\ 35,62 & 1 & 52 \\ 20,31-50 & 1 & 4 \\ 48,50-60^{\mathrm{h}} & 0.5 & 52 \\ 21,44 & 0.45^{\mathrm{i}} & 6 \\ 11,44 & & \end{array}$

$\begin{array}{lll}5.3 & -2(+2) & 64,151 \\ 6.4 & -3(+3) & \\ 5.5 & -1 & 152 \\ 6.3 & +8^{\star \star \star} & \\ 5.5 & -8^{\star \star} & 17,153 \\ 5.1 & +2(+6) & 144 \\ 5.4 & -5 & 154 \\ 5.3 & -13(+7){ }^{\star \star} & 155 \\ 5.0 & -6^{\star \star \star} & 156 \\ 5.2 & 0 & 146 \\ 5.8 & -14^{\star *} & 157 \\ 5.9 & -17(+5){ }^{\star *} & 158 \\ 6.2 & -10 & 159 \\ 5.3 & +10(+10) & 160 \\ 5.2 & -8^{\star \star} & 161 \\ 5.4 & 0(+5) & 162 \\ & +4(+5) & \\ 5.1 & -1^{c} & 163 \\ 5.4 & 0^{c} & \\ 5.6 & -2^{c} & 164 \\ & & \\ 5.6 & -5.2 & \end{array}$

$\begin{array}{lll}6.6 & -7(+5)^{\star \star} & 165 \\ 7.4 & -12^{\star \star} & \\ 7.9 & 0 & 166 \\ 6.8 & -13(-4)^{\star \star \star} & 154 \\ 6.6 & -12(-2) * \star & 155 \\ 8.6 & -19(-5) * \star \star & 167 \\ 7.2 & -9^{\star \star \star} & 168 \\ 9.4 & -19^{\star \star \star} & \end{array}$


TABLE 1 (continued)

Vitamin C and Plasma Cholesterol: Intervention Studies

\begin{tabular}{|c|c|c|c|c|c|c|c|}
\hline & \multirow{2}{*}{$\begin{array}{l}\text { No. subjects; } \\
\text { age, mean/ } \\
\text { range }(y)^{\mathrm{a}}\end{array}$} & \multirow{2}{*}{$\begin{array}{l}\text { Vitamin } \\
\text { dose } \\
(\mathrm{g} / \mathrm{d})\end{array}$} & \multirow{2}{*}{$\begin{array}{l}\text { Duration } \\
\text { of study } \\
\text { (weeks) }\end{array}$} & \multirow[b]{2}{*}{$\begin{array}{l}\text { Control } \\
\text { group }\end{array}$} & \multicolumn{2}{|c|}{ Pretreatment } & \multirow{2}{*}{$\begin{array}{l}\text { Change in } \\
\text { cholesterol } \\
\text { (\%) }\end{array}$} \\
\hline & & & & & $\begin{array}{c}\text { Vitamin } C \\
(\mu M)\end{array}$ & $\begin{array}{c}\text { Cholesterol } \\
(\mathrm{m} M)\end{array}$ & \\
\hline
\end{tabular}

Ref.

High initial plasma cholesterol (average over $6.5 \mathrm{mM}$ ):

\section{Vitamin C level was determined}

\begin{tabular}{|c|c|c|c|c|c|c|c|}
\hline Bordia 1980 & $40,40-60^{e}$ & $\begin{array}{l}2 \\
1\end{array}$ & 26 & DB & 30 & 7.4 & $\begin{array}{l}-11(0) \\
N S^{k}\end{array}$ \\
\hline Dobson et al. 1984 & 10,58 & $1-2$ & 52 & - & 59 & 7.0 & $-14^{*}$ \\
\hline Bishop et al. 1985 & $50,56^{\mathrm{h}}$ & 0.5 & 8 & DB & 41 & 7.0 & $-5(-5)$ \\
\hline Gulenc 1988 & $38,-$ & 2 & 8 & - & 43 & 6.9 & $-16^{\star * \star}$ \\
\hline \multirow[t]{3}{*}{ Ginter 1989} & $14,-1$ & $0.8^{i}$ & 18 & - & 44 & 11.4 & $-7 * \star$ \\
\hline & $13,-^{m}$ & & & & 28 & 9.3 & $-9^{\star \star \star}$ \\
\hline & $7,-^{\mathrm{h}}$ & & & & 43 & 9.6 & $-11 *$ \\
\hline
\end{tabular}

\section{Vitamin C level not reported}

$\begin{array}{lllllllll}\text { Samuel 1964 } & 14,42 & 1-6 & 5-16 & - & - & 9.7 & -2 & 173 \\ \text { Sokoloff et al. 1967 } & 109,47-78^{n} & 2-3 & 44-104 & \mathrm{P} & - & 8.0 & -21(-3)^{\circ} & 64,151 \\ \text { Ginter 1975 } & 24,62 & 1 & 26 & - & - & 6.6 & -17^{* * *} & 10 \\ \text { Filho et al. 1978 } & 19,75 & 2 & 2 & - & - & 6.7 & -43^{\circ} & 174 \\ \text { Heine and Norden 1979 } & 63,57^{\mathrm{e}} & 1 & 68 & - & - & 8.5 & -11^{\circ} & 175 \\ \text { Fidanza et al. 1982 } & 20,63 & 3 & 3 & - & - & 8.1 & -18^{\star \star} & 157 \\ \text { Wahlberg 1982 } & 9,55 & 2 & 4 & \mathrm{P} & - & 7.4 & 0(-2) & 176 \\ \text { Mamianetti et al. 1988 } & 14,48 & 1.5 & 3 & - & - & 6.5 & -9 & 177 \\ \text { Average, group 3: } & & & & & & & & \end{array}$

Note: control groups: DB, double-blind placebo control; P, placebo control; C, control group without placebo; -, no control group. Averages for the three groups: three studies ${ }^{143,163,164}$ are not included because they did not report the change from the pretreatment level. Only the higher dose group of two studies ${ }^{162,169}$ is included in the average, and one study ${ }^{160}$ was not included because the vitamin dose was only $0.15 \mathrm{~g} / \mathrm{d}$.

a The number of subjects includes the control group.

b In parenthesis: the change in the control group. The level of significance for the vitamin group as reported in the publications: ${ }^{\star}, p<0.05 ;{ }^{\star \star}, p<0.01 ;{ }^{\star \star \star}, p<0.001$.

c Comparison to control group.

d Subjects received three eggs per day.

- Patients with atherosclerosis.

f $300 \mathrm{mg}$ vitamin $\mathrm{E}, 27 \mathrm{mg} \beta$-carotene, and $75 \mu \mathrm{g}$ selenium were also given each day.

$g$ Subgroup with serum cholesterol values over $6.2 \mathrm{mM}$.

h Patients with diabetes.

i Pectin (15 g/d) was administered along with the vitamin C.

j Hyperlipemic outpatients, six of them with diabetes.

k No significant effect; data not provided.

1 Familial hypercholesterolemia.

m Polygenic hypercholesterolemia.

n Groups 3 to 6. pooled from Reference 151.

- No statistical analysis was made by the authors.

\section{A. Pretreatment Cholesterol Level}

Several studies in this area have used subjects with initially low levels of plasma cholesterol (group 1 in Table 1). The animal experiments and the biochemical data of the mechanism do not suggest that supplemental vitamin $\mathrm{C}$ would considerably decrease an initially low cholesterol 
level. Furthermore, while elevated cholesterol levels (above $5 \mathrm{mM}$ ) are associated with a progressive increase in mortality, especially due to coronary heart disease (CHD), an increase in mortality is also noted with low cholesterol levels (below $4.5 \mathrm{mM}$ ). ${ }^{178}$ Low levels of cholesterol have been associated with increased risk of cancer ${ }^{179}$ and hemorrhagic stroke, ${ }^{180}$ and such effects appear to overshadow the benefits of a minor decrease in CHD that may occur by lowering cholesterol levels below $5 \mathrm{mM} .{ }^{178}$

Accordingly, there is no clear biochemical basis for the expectation, and no apparent medical reason for the hope, that rather low cholesterol levels would be further decreased by vitamin $\mathrm{C}$ supplementation. Therefore, it seems quite surprising that several of the intervention studies have used subjects with initially low cholesterol levels (group 1). None of these studies found an actual decrease in the cholesterol level by the vitamin.

A number of studies have used subjects with initially medium levels of plasma cholesterol (group 2). These studies have mostly found minor or moderate decreases in cholesterol levels, which have been statistically significant in a few cases (Table 1). However, one of these studies reported a statistically significant increase in cholesterol level in one of the study groups. ${ }^{152}$

If low vitamin $C$ status decreases cholesterol catabolism, and increases cholesterol levels even in a subgroup of people, then one may expect the greatest effects of supplemental vitamin on a group with high cholesterol levels. Such a group could contain subjects in whom the cholesterol catabolism is limited by low levels of vitamin C. Several trials have used hypercholesterolemic subjects, and these studies have quite consistently reported a substantial decrease in the cholesterol level by vitamin $C$ supplementation (group 3 in Table 1). Only two studies ${ }^{166,176}$ in this group did not report any absolute decrease caused by the vitamin, and one study found no difference between the effects of vitamin and placebo. ${ }^{170}$

There has been a large variation in the technical quality of the intervention studies. Several of the studies did not use any kind of control group, and in many cases the control group did not receive a placebo (Table 1). In two studies the control group was not comparable to the vitamin group. ${ }^{154,165}$ Furthermore, the experimental design was poorly described in one of the placebo controlled studies that has shown a notable decrease in cholesterol level. ${ }^{64,151}$ Obviously, the calculation of statistical significance is rather doubtful in the absence of a proper control group that would give a satisfactory estimate of the placebo effect. However, for the technical details of the three dozen studies, the reader is referred to the original publications.

In a further analysis of the intervention studies, the placebo-controlled trials were considered separately (Figure 2). There is a significant correlation between the initial cholesterol level and the change in cholesterol level in the placebo groups $(\mathrm{r}=-0.90 ; p<0.001)$ and in the vitamin $\mathrm{C}$ groups $(\mathrm{r}=-0.86 ; p<0.001)$. According to these studies, vitamin $\mathrm{C}$ does not differ from placebo if the initial cholesterol level is about $4.5 \mathrm{~m} M$; at this level the placebo increases plasma cholesterol by some $5 \%$. The difference between vitamin $\mathrm{C}$ and placebo progressively increases with the increase in the pretreatment cholesterol level (Figure 2). In subjects with plasma cholesterol of $9 \mathrm{mM}$, the linear regression lines for the placebo and vitamin $\mathrm{C}$ group predict decreases of 6 and $18 \%$, respectively, in the cholesterol level.

Only three of the study groups match poorly with the regression lines (Figure 2). First, the cholesterol level $(4.1 \mathrm{~m} M)$ did not increase in another of the vitamin groups of Buzzard et al. ${ }^{150}$ Second, the decrease in cholesterol level (from $7.0 \mathrm{mM}$ ) by placebo in the study of Bishop et al. ${ }^{170}$ was significantly larger than expected by the regression line: -5 vs. $0 \%$, respectively. Third, Wahlberg and Walldius ${ }^{176}$ observed absolutely no effect by vitamin $\mathrm{C}$ on the cholesterol level $(7.4 \mathrm{mM})$, whereas the regression line predicts a decrease of $10 \%$. Still, the agreement of the results with the two regression lines is striking, when taking into consideration the large variations in the studies with respect to the selection of the subjects, the design of the study, etc.

It is noteworthy that placebo causes an increase in low cholesterol levels, but a decrease in high levels (Figure 2). The increase in low cholesterol levels by placebo has in general not 


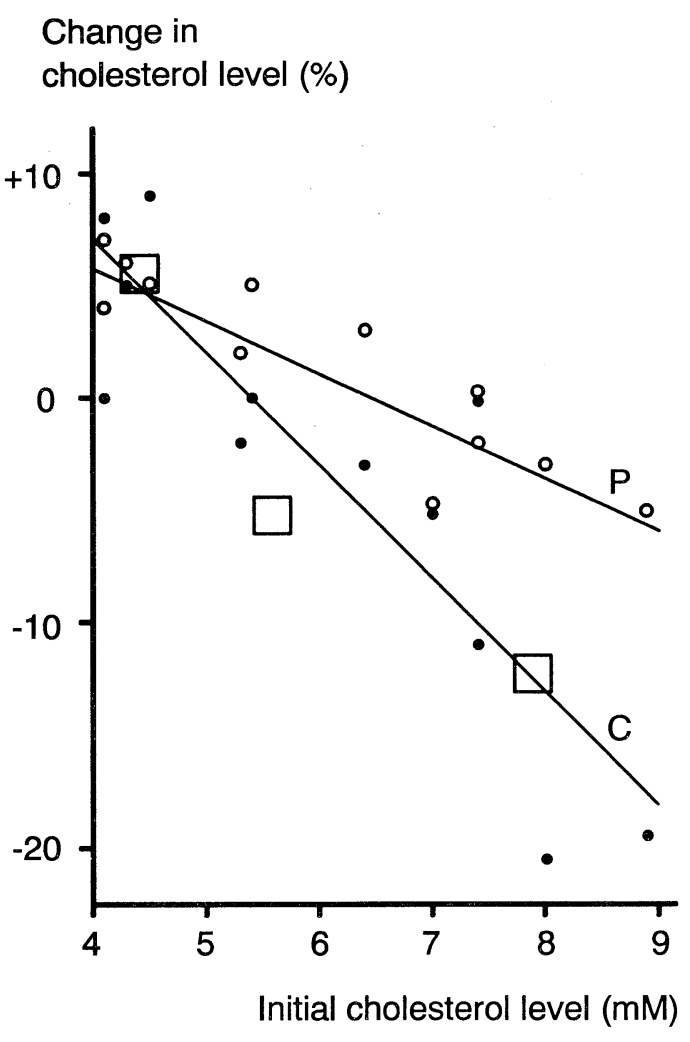

FIGURE 2. Change in cholesterol levels in placebo groups (o) and vitamin $\mathrm{C}$ groups $(\bullet)$. The studies are taken from Table 1 (control group: $P$ or DB). Two studies ${ }^{143,164}$ are not included because only the difference between the vitamin and placebo groups was reported, and thus the changes from the pretreatment cholesterol level are not known. Only the higher vitamin $C$ dose groups of two other studies ${ }^{162,169}$ were included. Linear regression lines for the placebo $(P)$ and vitamin $C(C)$ groups are shown.

been considered appropriately. For example, Aro et al. ${ }^{162}$ found no effect at all on cholesterol by vitamin $\mathrm{C}$, whereas the placebo caused an increase by $5 \%$. This was considered to be an indication that vitamin $\mathrm{C}$ does not affect cholesterol metabolism. However, the pretreatment cholesterol level was $5.4 \mathrm{mM}$, and at this level the regression lines suggest no effect of vitamin $C$, but a small increase by the placebo (Figure 2). Thus, paradoxically, in this case a zero effect by vitamin $\mathrm{C}$ may indicate a meaningful difference from placebo. However, the observation was not statistically significant because such a small number of subjects were used. ${ }^{162}$ The behaviour of the placebo groups (Figure 2) may be due to regression toward mean.
The regression lines are not markedly affected if those studies that used control groups that were not administered a placebo are also included. Furthermore, the averages for the three groups of Table 1 fall quite close to the vitamin C-regression line (Figure 2). An inspection of the placebo groups (Table 1 and Figure 2) indicates that the decreases in cholesterol that were reported in the uncontrolled studies of group 3 are not explainable by just a placebo effect. So far, the largest decreases in cholesterol level by a placebo have been only $-5 \%$, whereas 13 studies in group 3 have reported larger decreases in plasma cholesterol than that (Table 1).

Accordingly, the pretreatment level of cholesterol seems to be an important factor in determining whether supplemental vitamin $\mathrm{C}$ causes a decrease in the plasma cholesterol levels of the subjects. The importance of pretreatment cholesterol level was previously suggested by the Russian authors, ${ }^{1}$ and by Ginter, who observed the role of initial cholesterol level in two studies ${ }^{154,165}$ and in an analysis of several of his own trials. ${ }^{181}$ Still, there are also other factors that differ between and may affect the discordance of the results.

\section{B. Other Factors Possibly Affecting the Results}

On biochemical grounds one may expect that the effect of vitamin $C$ is saturable. Thus, if the initial vitamin $C$ level is very high one should not expect any noticeable effect of additional vitamin, since in such a case hypercholesterolemia may not be caused, even partially, by a marginal vitamin deficiency. It is noteworthy that the study by Peterson et al., ${ }^{166}$ which found no effect of the vitamin, used subjects that had the highest pretreatment vitamin $\mathrm{C}$ level of group 3a. Apparently, with such high vitamin $C$ levels (85 $\mu M)$, the vitamin may not be rate limiting in cholesterol catabolism. In fact, such a high base line vitamin level suggests that the diet of the subjects contained over $300 \mathrm{mg} / \mathrm{d}$ of vitamin $C,{ }^{147,155,162-164,167-170,182}$ which is much higher than the RDA recommendation $(60 \mathrm{mg} / \mathrm{d}$; Reference 183).

The vitamin dose may also affect the results. Bordia ${ }^{169}$ observed a notable decrease in plasma cholesterol level with $2 \mathrm{~g} / \mathrm{d}$ of vitamin $\mathrm{C}$, but not 
with the smaller amount of $1 \mathrm{~g} / \mathrm{d}$. Aro et al. ${ }^{162}$ found that when compared with the placebo, 2 $\mathrm{g} / \mathrm{d}$ of vitamin $\mathrm{C}$ decreased plasma cholesterol level by $-5 \%$, whereas $0.2 \mathrm{~g} / \mathrm{d}$ decreased it by only $-1 \%$. Thus, the effect of the vitamin seems to be dose dependent. The amount of vitamin used by Burr et al. ${ }^{160}$ Salonen et al., ${ }^{164}$ and Bishop et al. ${ }^{170}$ which did not show any benefit compared with the placebo, were among the smallest of all studies $(0.15$ to $0.6 \mathrm{~g} / \mathrm{d})$. However, decrease in the plasma cholesterol level by a small dose of the vitamin $(0.3$ to $0.5 \mathrm{~g} / \mathrm{d})$ has been reported in some trials, ${ }^{165,167,168}$ and there is no obvious correlation between the dose and the decrease in the cholesterol level in studies of group 3a. Thus, no clear dose-effect relationships may be inferred from the results available, aside from the two studies referred to above. ${ }^{162,169}$

The duration of the study may also affect the results. Dobson et al. ${ }^{158}$ observed that in older subjects (average 58 years), vitamin C slowly decreased the cholesterol levels over a period of 1 year, while the decrease was much faster in younger subjects. Similarly Sokoloff et al. ${ }^{64,151}$ observed a slow decrease in plasma cholesterol levels in elderly people (average 60 years) over a 1 year time period. This suggests that the length of the trial may be an important factor in the case of elderly subjects. A few trials with elderly people have lasted for a relatively short period, ${ }^{152,170,176}$ which could affect the results.

Several studies have indicated that there are large individual variations in the response to vitamin C supplementation. Ginter et al. ${ }^{154,167,168}$ noted that approximately one third of their subjects did not show any benefit from the vitamin. Sokoloff et al. ${ }^{64,151}$ found no effect in $20 \%$ of the hypercholesterolemic subjects used, but found varying benefits for others. Samuel and Shalchi ${ }^{173}$ found a statistically significant decrease in plasma cholesterol levels in 3 persons out of 14 , whereas none of the subjects experienced a significant increase. Such large differences in individual responses may depend on several factors. The groups are heterogeneous with respect to pretreatment levels of cholesterol and vitamin $\mathrm{C}$. Furthermore, there may be large differences in individual responses to low vitamin $\mathrm{C}$ levels in human beings, in the same manner as has been observed in guinea pigs. ${ }^{184,185}$ Accordingly, certain individuals could be sensitive to low levels of vitamin $\mathrm{C}$ regarding the catabolism of cholesterol, even if the majority were not.

Moreover, there are also other factors affecting plasma cholesterol levels. For example, nutritional factors such as dietary palmitate, cholesterol and fiber, ${ }^{186-189}$ and genetic factors ${ }^{190,191}$ are important in determining plasma cholesterol levels. Holloway et al. ${ }^{31}$ found that in guinea pigs the effect of marginal vitamin $\mathrm{C}$ deficiency on cholesterol levels and bile acid metabolism depended on the type of feed given, thus underscoring the role of basic diet. Unfortunately, the diets used in the intervention studies have not been described in such detail that the role of, for example, dietary fats, cholesterol, or fiber could be evaluated as a possible explanation for some of the variation in the results. A combination of vitamin $C$ and pectin was used in two groups, ${ }^{168,172}$ but there were no control groups to determine whether the observed effect differs from that of vitamin $\mathrm{C}$ alone (or pectin alone). Also, there is a limited amount of information describing the subjects in the studies. Thus, one cannot conclude whether the effect of vitamin $C$ depends on the type of hyperlipidemia that the patients suffer; one would expect only a small effect in patients with familial hypercholesterolemia.

The inaccuracy in the measurement of vitamin $\mathrm{C}$ and cholesterol levels, as well as withinperson variation in the level from day to day may also partially account the differences among studies. These factors are most important in studies using a small number of subjects. On the other hand, the role of these and other random variables should be markedly decreased when averaging the results of several studies; for that purpose the averages for the three groups was calculated ( $\mathrm{Ta}$ ble 1, Figure 2).

Of the factors discussed, the pretreatment level of cholesterol seems to be by far the most important in predicting the effect of vitamin C. High pretreatment vitamin $\mathrm{C}$ level and low vitamin dose indicate that only a small effect may be expected, but the data are too limited for any quantitative conclusions with respect to these factors. Furthermore, there may be large individual variations in the effects of vitamin $\mathrm{C}$ on choles- 
terol metabolism, and the duration of the study may be important, especially in the case of elderly subjects.

\section{HDL-Cholesterol and Triglycerides}

HDL-cholesterol levels are inversely related to the risk of CHD, and HDL-cholesterol appears to be a stronger indicator for that risk than total plasma cholesterol. ${ }^{86,193,194}$ The level of HDLcholesterol has been measured in several intervention studies. In some studies the level of HDLcholesterol was increased by vitamin $\mathrm{C}$ supplementation and this reached statistical significance in six study groups (Table 2). Furthermore, Buzzard et al. ${ }^{150}$ found a considerable increase in the HDL-cholesterol levels in three individuals that had the lowest base line vitamin $C$ levels. So far, no obvious biochemical mechanism is known whereby one should expect vitamin $C$ to increase the HDL-cholesterol level specifically, but the apparent effect of the vitamin on lipoprotein lipase could be such a link (see Sections II.D and III).

An elevated triglyceride level appears to be a risk factor for CHD, but it is usually associated with other risk factors, such as low HDL-cholesterol, and thus it has been difficult to evaluate its precise significance. ${ }^{195}$ The effect of vitamin $\mathrm{C}$ on triglyceride levels has been studied in 27 groups of subjects (Table 2). It is notable that a decrease in triglyceride levels has been reported in 20 study groups. The triglyceride level was increased only in three study groups: in one study the change in triglyceride levels was $-8 \%$ after 3 weeks, but $+20 \%$ after 6 weeks, ${ }^{168}$ and in another study the increase in the placebo group was even higher. ${ }^{170}$ Bishop et al. ${ }^{170}$ found a notable, but not statistically significant, decrease in triglyceride levels in subjects with initially very low vitamin C levels. The results of Sokoloff et al. ${ }^{151}$ suggest that the effect of vitamin $C$ could be more pronounced in subjects with elevated triglyceride levels (Table 2). Interestingly, Geoly and Diamond ${ }^{196}$ observed in a brief report that the elevated triglyceride levels ( 9 and $12 \mathrm{mM}$ ) of two patients were decreased by $60 \%$ with the administration of vitamin $\mathrm{C}(3 \mathrm{~g} / \mathrm{d})$.
Vitamin C could decrease triglyceride levels by affecting lipoprotein lipase activity or carnitine synthesis (see Section III). Sokoloff et al ${ }^{64,151}$ found that concomitantly with the decrease in triglyceride levels by the vitamin, the activity of lipoprotein lipase steadily increased in the patients. Davies et al. ${ }^{197}$ found that supplementation of elderly men with vitamin $\mathrm{C}(0.2 \mathrm{~g} / \mathrm{d})$ resulted in an increase of urinary excretion of carnitine, and ending of supplementation reduced the excreted carnitine level. They found also a positive correlation between levels of leukocyte vitamin $\mathrm{C}$ and urinary carnitine $(\mathrm{r}=0.5, p=<0.01)$. However, in another study no effect of vitamin C on urinary carnitine was found. ${ }^{198}$

Thus, the intervention studies suggest that in some cases vitamin C may increase HDL-cholesterol levels and decrease triglyceride levels. However, because the results are not quite consistent, and most of the studies have lacked a proper control group, the conclusions may be only preliminary. Possibly more pronounced and less-disputable effects could be observed in properly controlled studies with subgroups that have, for example, low HDL-cholesterol levels or elevated triglyceride levels.

\section{EPIDEMIOLOGICAL STUDIES}

\section{A. Cholesterol, HDL-Cholesterol, and Triglycerides}

Numerous cross-sectional studies have been carried out to determine whether there is a correlation between plasma vitamin $\mathrm{C}$ level and the levels of total cholesterol or HDL-cholesterol (Table 3). If a low vitamin level tends to increase plasma cholesterol levels, then a negative correlation between vitamin $\mathrm{C}$ and cholesterol should be observed, which has been the case in a majority of the studies. In several cases, the negative correlation has been significant statistically (Table 3). A single notable exception to this general pattern is the study by Saha and Tan, ${ }^{215}$ which found a statistically significant positive correlation between the levels of vitamin $\mathrm{C}$ and cholesterol. 
TABLE 2

The Effect of Vitamin C on HDL Cholesterol and Triglyceride Levels

\section{Study}

Sokoloff et al. 1967

Sokoloff et al. 1967
Menne et al. 1975
Peterson et al. 1975
Ginter et al. 1978
Ginter et al. 1979
Heine and Norden 1979
Bordia 1980 (2 g/d)
Horsey et al. 1981

Johnson and Obenshain 1981
Joshi et al. 1981
Khan and Seedarnee 1981
Buzzard et al. 1982
Fidanza et al. 1982
Wahlberg and Walldius 1982
Koh 1984
Bishop et al. 1985
Erden et al. 1985
Aro et al. 1988 (2 g/d)
Gulenc and Nebioglu 1988
O'Brien and McMurray 1988
Ginter 1989

Salonen et al. 1991
HDL-

No. cholesterol Change Triglycerides Change $\begin{array}{lllll}\text { subjects } & (\mathrm{m} M) & (\%) & (\mathrm{m} M) & (\%)\end{array}$

Ref.

\begin{tabular}{|c|c|c|c|c|c|}
\hline 40 & - & & 0.76 & $-3(-1)$ & 151 \\
\hline 28 & & & 1.1 & $-5(+2)$ & \\
\hline 35 & & & 1.4 & $-37(+1)$ & \\
\hline 12 & & & 1.8 & $-6(-3)$ & \\
\hline 36 & & & 2.0 & $-41(-8)$ & \\
\hline 26 & & & 2.4 & $-51(-5)^{a}$ & \\
\hline 122 & - & & 1.3 & $-25(-22)$ & 145 \\
\hline 9 & 0.67 & -34 & 1.7 & -13 & 166 \\
\hline 48 & - & & 2.6 & $-18(-2)^{\star}$ & 167 \\
\hline 21 & 1.5 & -5 & 2.2 & +20 & 168 \\
\hline 63 & - & & 3.8 & 0 & 175 \\
\hline 30 & - & & 1.8 & $-5(0)$ & 169 \\
\hline 7 & 0.80 & +19 * & 1.1 & +7 & 146 \\
\hline 7 & 1.5 & -5 & 1.5 & 0 & \\
\hline $6^{\mathrm{b}}$ & 0.67 & +31 * & 1.8 & -14 & \\
\hline $5^{\mathrm{b}}$ & 1.2 & +21 * & 2.2 & $-27^{*}$ & \\
\hline 9 & 1.1 & $+5(+4)$ & 1.1 & $0(+8)$ & 147 \\
\hline 27 & 1.8 & -3 & - & & 148 \\
\hline 13 & 1.5 & 0 & 0.67 & -5 & 149 \\
\hline 40 & 1.2 & $+2(-2)$ & - & & 150 \\
\hline 20 & - & & 2.0 & -12 * & 157 \\
\hline 9 & 1.1 & $0(+4)$ & 4.8 & $0(-14)$ & 176 \\
\hline 23 & 1.1 & 0 & 2.5 & -35 * & 159 \\
\hline 50 & - & & 2.8 & $+11(+19)$ & 170 \\
\hline 15 & 1.5 & $+27^{*}$ & 1.7 & $-21 *$ & 161 \\
\hline 27 & 1.2 & $-2(0)$ & 1.3 & $-8(+6)$ & 162 \\
\hline 31 & 1.4 & $+13^{*}$ & 1.6 & $-14^{*}$ & 171 \\
\hline \multirow[t]{2}{*}{20} & 1.1 & $-9^{c}$ & 1.4 & $-10^{c}$ & 163 \\
\hline & 1.0 & $+7^{c}$ & 1.5 & $-15^{c}$ & \\
\hline 14 & 1.4 & $+7^{\star}$ & - & & 172 \\
\hline 13 & 1.4 & +2 & & & \\
\hline 7 & 1.1 & +9 & & & \\
\hline 39 & 1.3 & $-5^{c}$ & - & & 164 \\
\hline
\end{tabular}

Note: For the age of subjects, vitamin dose, and the duration of the study see Table 1. Number in parenthesis shows the change in the control group. Statistical significance: ${ }^{*}, p<0.05$. Triglyceride levels in $(\mathrm{mg} / \mathrm{dl})-$ units were converted to $(\mathrm{mM})$-units, assuming that $1 \mathrm{mM}$ corresponds to $88 \mathrm{mg} / \mathrm{dl}^{192}$

a Control group was poorly matching: average triglyceride level was $1.9 \mathrm{mM}$.

b Patients with CAD.

c Comparison to control group. 
TABLE 3

Vitamin C, Plasma Cholesterol and HDL-Cholesterol: Cross-Sectional Studies

\begin{tabular}{|c|c|c|c|c|c|}
\hline Study & $\begin{array}{c}\text { No. of subjects; } \\
\text { age, mean/range }(y)\end{array}$ & $\begin{array}{l}\text { Plasma vitamin } C, \\
\text { average }(\mu M)\end{array}$ & $\begin{array}{l}\text { Cholesterol, } \\
\text { correlation } \\
\text { coefficient }^{\mathrm{a}}\end{array}$ & $\begin{array}{l}\text { HDL-cholesterol, } \\
\text { correlation } \\
\text { coefficient }^{\mathrm{a}}\end{array}$ & Ref. \\
\hline Masek 1960 & $35,-$ & 40 & -0.42 * & - & 199 \\
\hline Cheraskin and Ringsdorf 1968 & 127,22 & 25 & $\begin{array}{l}-0.2 b \\
-0.08 \\
+0.27^{b} \star \star\end{array}$ & - & 200 \\
\hline Kajaba and Bucko 1968 & $>450,7-11$ & 60 & - neg ${ }^{\star \star \star}$ & - & 201 \\
\hline Elwood et al. 1970 & 154 , adults & 35 & +0.02 & - & 202 \\
\hline Jain et al. 1976 & $150,18-50$ & 40 & -0.31 ** & - & 203 \\
\hline Bates et al. 1977 & $\begin{array}{l}11,72-86, \text { female } \\
12,72-86, \text { male }\end{array}$ & $\begin{array}{l}30 \\
15\end{array}$ & $\begin{aligned} & 0.0 \\
+ & 0.30\end{aligned}$ & $\begin{array}{l}-0.28 \\
+0.71\end{array}$ & 204 \\
\hline Cerna and Ginter 1978 & $600,25-55$ & - & $-0.18^{\mathrm{c} \star \star \star}$ & - & 205 \\
\hline Koh and Stewart 1978 & $304,5-80$ & - & -0.05 & - & 206 \\
\hline Bates et al. 1979 & $\begin{array}{l}228,77, \text { female } \\
109,76, \text { male }\end{array}$ & $\begin{array}{l}20 \\
15\end{array}$ & $\begin{array}{l}\text { NS } \\
\text { NS }\end{array}$ & $\begin{array}{l}+0.13^{*} \\
+0.12\end{array}$ & 207 \\
\hline Olusi et al. 1979 & $\begin{array}{l}57,32 \\
30,35^{d} \\
32,33^{d}\end{array}$ & $\begin{array}{l}90 \\
50 \\
50\end{array}$ & $\begin{array}{l}-0.34 \\
-0.61 \text { * } \\
-0.49 \text { * }\end{array}$ & E & 208 \\
\hline Koh and Chi 1980 & $\begin{array}{l}245,>34, \text { female } \\
184,>34, \text { male }\end{array}$ & - & $\begin{array}{l}+ \text { pos } \\
- \text { neg }\end{array}$ & & 209 \\
\hline Dwyer et al. 1981 & 530,21 & - & - & NS ${ }^{e}$ & 210 \\
\hline Horsey et al. 1981 & $\begin{array}{l}12,87, \text { female } \\
13,77, \text { male }\end{array}$ & - & - & $\begin{array}{l}N^{c} \\
+0.60^{c} \text { * }\end{array}$ & 146 \\
\hline Burr et al. 1982 & 97,51 , male & 45 & $-0.23^{*}$ & +0.21 * & 211 \\
\hline Burr et al. 1982 & 97,46 , female & 50 & +0.12 & +0.21 * & 212 \\
\hline Greco and Rocca 1982 & $70,70-84$ & 30 & $-0.27^{\star}$ & - & 213 \\
\hline Hooper et al. 1983 & 270,72 & 70 & NS & NS & 214 \\
\hline Saha and Tan 1983 & 198,24 & 65 & + pos * & - & 215 \\
\hline Church et al. 1984 & $\begin{array}{l}16,34, \text { female } \\
13,35, \text { male }\end{array}$ & $\begin{array}{l}100 \mathrm{mg} / \mathrm{d}^{\mathrm{e}} \\
140 \mathrm{mg} / \mathrm{d}^{\mathrm{e}}\end{array}$ & - & $\begin{array}{l}+0.54^{e^{*}} \\
+0.53^{e}\end{array}$ & 216 \\
\hline Yoshioka et al. 1984 & $194,30-39$ & 40 & -0.07 & -0.02 & 217 \\
\hline Mayet et al. 1986 & 382,44 & - & $-0.02^{\mathrm{c}}$ & & 218 \\
\hline Jacques et al. 1987 & 680,73 & $>55^{4}$ & $+0.03^{\mathrm{g}}$ & $+0.09^{9}$ * & 219 \\
\hline Kothari et al. 1988 & $104,0-85$ & 50 & $-0.66^{\star \star}$ & - & 220 \\
\hline Aro et al. 1988 & 27,81 & - & -0.05 & - & 162 \\
\hline O'Brien and McMurray 1988 & 20,45 & - & $\begin{array}{l}\text { NS } \\
- \text { neg }^{*} \text { * }\end{array}$ & $\begin{array}{l}+ \text { pos }^{*} \\
\text { NS }^{c}\end{array}$ & 163 \\
\hline Salonen et al. 1988 & 1132,54 & 40 & - & NS & 221 \\
\hline Dallal et al. 1989 & $146,60-96$, female & 60 & - & $\begin{array}{l}+0.21^{g *} \\
+0.22^{g, h}\end{array}$ & 222 \\
\hline & $92,60-96$, male & 45 & - & $\begin{array}{l}+0.10^{g} \\
+0.43^{g, h} * *\end{array}$ & \\
\hline Itoh et al. 1990 & $\begin{array}{l}96,71, \text { female } \\
79,71, \text { male }\end{array}$ & $\begin{array}{l}60 \\
50\end{array}$ & $\begin{array}{l}-0.31^{\star *} \\
-0.03\end{array}$ & $\begin{array}{l}+0.37^{* *} \\
+0.24^{*}\end{array}$ & 223 \\
\hline
\end{tabular}


-ABLE 3 (continued)

/itamin C, Plasma Cholesterol and HDL-Cholesterol: Cross-Sectional Studies

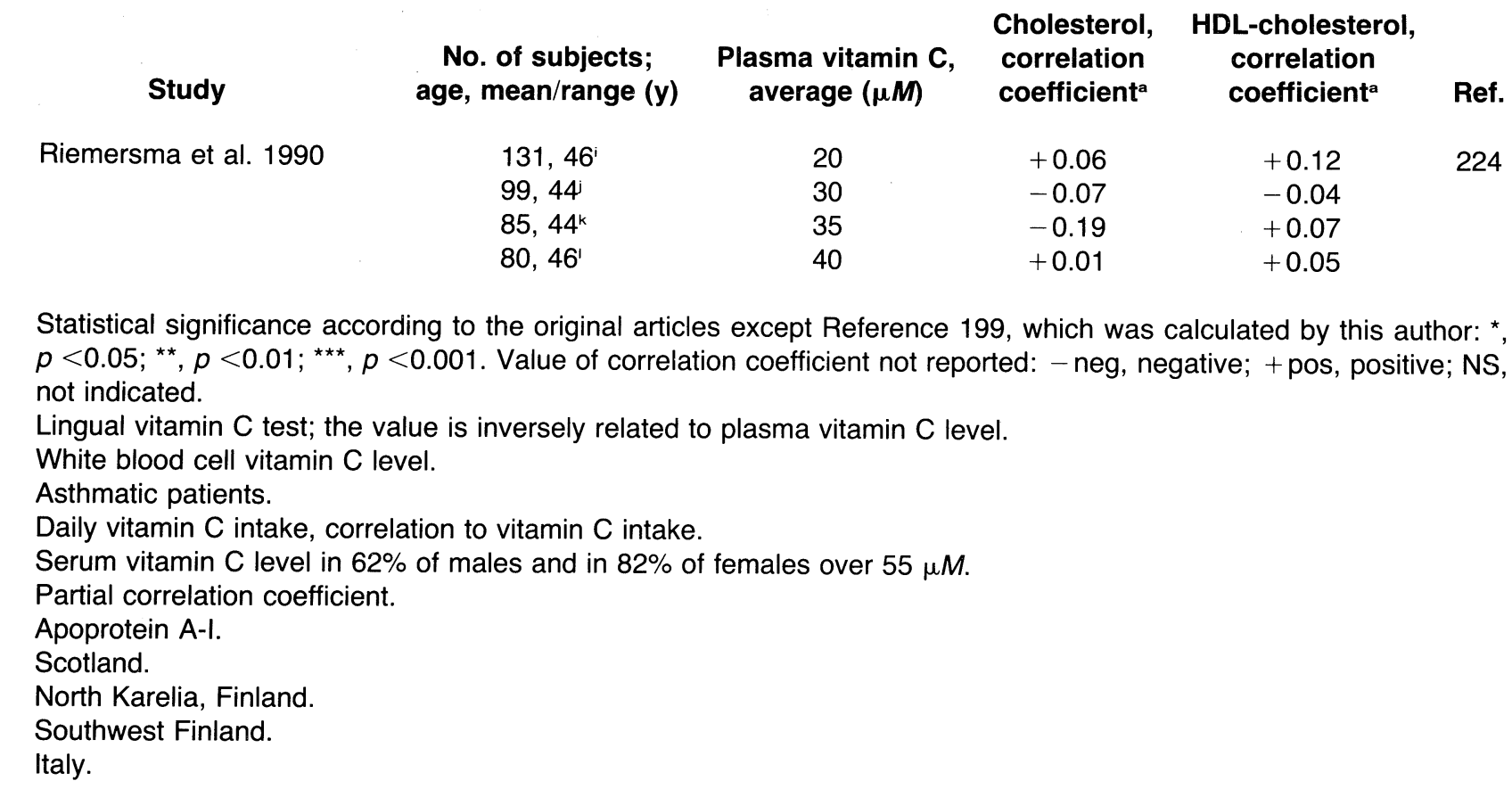

Vitamin C levels decrease and cholesterol levels increase with age, ${ }^{203,220,225}$ which could be due to the former process effecting the latter. However, there are other factors that may also increase cholesterol levels with age, and therefore the significance of the decrease in vitamin $\mathrm{C}$ level is not clear. Although several of the epidemiological studies have used both young and old subjects, the role of age has not been considered. However, some studies have used subjects of a small age range, ${ }^{200,201,213,223}$ and the results of these studies indicate that the correlation between vitamin $\mathrm{C}$ and cholesterol is not just secondary to the effect of age on both factors.

Various studies have also examined the relationship between vitamin $\mathrm{C}$ and HDL-cholesterol (Table 3). Except for three study groups, ${ }^{204,217}$ a positive correlation has been found consistently, and in several cases the correlation has reached a level of statistical significance (Table 3). It is notable that the positive association between vitamin $\mathrm{C}$ and HDL-cholesterol is more consistent in the cross-sectional studies than in the intervention studies (Table 2).

Five studies have reported a negative correlation between the levels of vitamin $\mathrm{C}$ and tri- glycerides, ${ }^{205,209,213,217,223}$ and two of these correlations were statistically significant. ${ }^{205,223}$ As far as this author is aware, no study has reported a positive correlation between vitamin $\mathrm{C}$ and triglyceride levels.

The cross-sectional studies probably underestimate the true magnitude of the role of vitamin $\mathrm{C}$, since the relationship may be attenuated by several factors such as the inaccuracy of measurements, within-person fluctuations in the levels of cholesterol ${ }^{226,227}$ and vitamin $C,{ }^{147,228}$ and variations in other factors affecting cholesterol levels (diet, genetics, etc.). In addition, the relationship between vitamin $\mathrm{C}$ level and cholesterol metabolism may differ among individuals. The large variations caused by such factors could result in observed correlational coefficients that underestimate the true relationship in the case of sensitive individuals (for an analogous case see Reference 229). Accordingly, vitamin C could be a moderately important determinant for the plasma level of cholesterol and HDL-cholesterol in some subgroups of normal populations. It is interesting that Olusi et al. ${ }^{208}$ found a low negative correlation between the vitamin $\mathrm{C}$ and cholesterol levels in a control group, whereas in two 
groups of asthmatic patients the negative correlation was significant.

\section{B. Mortality and Morbidity}

Some epidemiological studies have analyzed the connection of vitamin $\mathrm{C}$ levels to mortality and morbidity from atherosclerosis. In different regions of Great Britain, the mortality from CHD and cerebrovascular disease was found to be negatively correlated with the average vitamin $\mathrm{C}$ intake that varied in the range of 48 to $57 \mathrm{mg} / \mathrm{d} .{ }^{3,230}$ A similar inverse correlation ${ }^{231}$ was also found with CHD and the amount of fruits and green vegetables eaten, which are good sources of vitamin C. A comparison of 16 populations of European countries found that low vitamin $\mathrm{C}$ levels were more common in regions with high mortality rate from CHD. ${ }^{232}$ However, the correlation with vitamin $\mathrm{E}$ level was stronger. A comparison of 22 districts of Scotland found low vitamin C levels as the most notable dietary factor associated with mortality from CHD. ${ }^{233}$

In one case-control study, ${ }^{234}$ it was found that subjects with abnormal coronary arteries had significantly lower leukocyte vitamin $C$ levels than subjects of the control group. In another case control study, patients with angina pectoris were found to have significantly lower vitamin $\mathrm{C}$ concentrations than controls. ${ }^{235}$

A steady fall in mortality rate from CHD has been observed in the U.S. It has been pointed out that concomitantly the gross production of vitamin $\mathrm{C},{ }^{236}$ and the consumption of fruits ${ }^{237}$ have increased. Whether this is due to a causal relationship or to chance is an open question. Lastly, a negative correlation between vitamin C level and blood pressure has been reported in some studies. ${ }^{159,206,209,217,230,238-240}$

\section{CONCLUSIONS}

Animal studies have shown that vitamin $\mathrm{C}$ participates in cholesterol metabolism, and the most significant effect of the vitamin appears to be on the catabolism of cholesterol. Several in- tervention studies suggest that vitamin C may also have a substantial role in human cholesterol metabolism. However, epidemiological studies have usually found a low correlation between vitamin $\mathrm{C}$ status and plasma cholesterol, and, thus, it is possible that only a subgroup of people respond to low vitamin $\mathrm{C}$ levels with a notable elevation in plasma cholesterol levels. In animal studies, the effects of low vitamin levels are more pronounced when the animals are fed an atherogenic diet. This invites speculation that low vitamin $\mathrm{C}$ levels could be more critical for people that, for example, eat foods that are rich in saturated fat and cholesterol.

\section{A. Nutritional Recommendations}

Although no final conclusions about the medical significance of vitamin $C$ in cholesterol metabolism may be made from the intervention studies carried out so far, the results evoke thoughts about the basis of nutritional recommendations. With respect to vitamin $\mathrm{C}$, the nutritional recommendations are concerned only with the prevention of frank scurvy. ${ }^{183,241-247}$

The RDA recommendations ${ }^{183}$ conclude that vitamin $\mathrm{C}$ does not affect plasma cholesterol level. This is based on the study of Peterson et al., ${ }^{166}$ which did not use any kind of control group, but used subjects that had a very high initial vitamin $\mathrm{C}$ level $(85 \mu M)$. Still, this study is provided as a disproof of one study by Ginter et al.,${ }^{154}$ which is the only reference that is mentioned to suggest that vitamin $\mathrm{C}$ might decrease elevated plasma cholesterol levels. This latter study is not placebo controlled either. However, ten placebo-controlled studies were published before the recommendations (Table 1), and five of these used subjects with elevated cholesterol levels. Nevertheless, none of these studies is referred to in the RDA recommendations. ${ }^{183}$ Accordingly, the selection of references may give a misleading impression of the number, quality, and results obtained in the intervention studies carried out prior to the publication of the RDA recommendations.

The recommendations consider that amounts greater than $1 \mathrm{~g}$ of vitamin $\mathrm{C}$ falls into the category of pharmacological use. ${ }^{183}$ However, the 
animals that synthesize vitamin $C$ by themselves make amounts of 1 to $10 \mathrm{~g} / \mathrm{d}$ when extrapolated to human size. ${ }^{243}$ Furthermore, an evolutionarily close relative of ours, the gorilla, eats approximately $4 \mathrm{~g} / \mathrm{d}$ of vitamin $\mathrm{C},{ }^{248}$ and the diet of our remote ancestors probably contained 0.4 to $2 \mathrm{~g} /$ $\mathrm{d}$ of the vitamin. ${ }^{81,249}$ Therefore, such levels do not appear to be unfamiliar to human physiology. Consequently, the levels that have been used in most of the intervention studies $(0.3$ to $2 \mathrm{~g} / \mathrm{d})$ should not be considered, a priori, as strictly pharmacological, even if they are considerably larger than the RDA recommendation of $60 \mathrm{mg} /$ d.

The recommendations are based on a poorly defined concept of "nutrient need", which appears to lack a valid biochemical basis. ${ }^{241,242,247}$ Recommendations are only intended to provide reasonable reserves to protect against frank scurvy, and they are not based on any studies suggesting that such a level would be best for long-term health. ${ }^{183,241-246}$ In fact, several studies have suggested that low levels of vitamin C may be associated with increased morbidity and mortality due to causes that are unrelated to scurvy. ${ }^{230-235,245,250-270}$ Even though the significance of these observations is not quite clear, a complete neglect of them seems unwise.

Scurvy is mostly attributed to a decrease in collagen synthesis. ${ }^{19,243}$ However, vitamin C also participates in several other enzymatic $^{19,243,246,271-273}$ and nonenzymatic ${ }^{96-101,270,274,275}$ functions, in addition to collagen metabolism. These other reactions may not necessarily proceed with optimal rates, even if the obvious signs of scurvy are absent. Amounts of vitamin C surpassing the recommendation have been suggested to be beneficial for the protection against nitrite ${ }^{275}$ and oxygen radicals, ${ }^{97}$ and for the degradation of cholesterol and xenobiotic substances. ${ }^{246}$ Consequently, the lack of frank scurvy should not be used as the principal criterium upon which to base a decision as to whether vitamin $\mathrm{C}$ levels are adequate for long-term health.

\section{B. Prevalence of Low Vitamin C Levels}

When the signs of scurvy appear, the plasma concentration of vitamin $\mathrm{C}$ has fallen to ap- proximately $5 \mu M$, but there are marked individual variations in the emergence of the symptoms. ${ }^{129,131,263}$ With a daily intake corresponding to the recommendation of $60 \mathrm{mg} / \mathrm{d}$, the median vitamin $\mathrm{C}$ level in plasma is $25 \mu \mathrm{M}$ in elderly men. ${ }^{182}$ On the other hand, the intake of gram amounts of the vitamin may increase the plasma concentration to 100 to 200 $\mu M{ }^{145,158,159,162,166,276-278}$ Thus, even in the absence of frank deficiency the variation in the vitamin $\mathrm{C}$ intake may cause over twentyfold variation in the plasma vitamin level, which may be reflected on the rates of several vitamin C-dependent reactions.

Low vitamin $C$ levels are not infrequent. In one study, ${ }^{224}$ the median concentration of plasma vitamin $\mathrm{C}$ in randomly chosen adult men from Italy, Finland, and Scotland was 38, 33, and 18 $\mu M$, respectively. Five percent of the subjects studied had a vitamin level below 10, 6, and 6 $\mu M$, respectively, in the three countries. Furthermore, in some groups of elderly people ${ }^{160,263}$ the mean vitamin $\mathrm{C}$ level may be as low as 10 $\mu M$. Accordingly, considerable segments of industrialized societies appear to have low vitamin $\mathrm{C}$ status, and therefore it is not only an academic question whether long-term marginal vitamin $\mathrm{C}$ deficiency increases cholesterol levels in certain susceptible individuals. It is possible that intakes larger than the recommended $60 \mathrm{mg} / \mathrm{d}$ would be beneficial for health, even though no definite conclusions may be made from the data available. Vitamin $\mathrm{C}$ is a cheap and safe nutrient, and several of the suspected side-effects of gram amounts have appeared to be unfounded; ${ }^{279}$ yet, diarrhea ${ }^{266}$ seems to be a common consequence in healthy people if they ingest 4 to $10 \mathrm{~g} / \mathrm{d}$.

Simonson and Keys ${ }^{1}$ concluded in their review of the early Russian studies that, "the reports reviewed here require a careful consideration. Repetition of some of the studies, with more attention to controls and statistical analysis, would be essential for critical evaluation', Much work has been done since their review. Vitamin $C$ has been shown to affect cholesterol catabolism in several animal species. However, the significance of vitamin $\mathrm{C}$ in cholesterol metabolism in humans is not settled, and the suggestions of the above authors are still valid. Obviously, further studies are required that are better planned with 
respect to the selection of experimental subjects, and the use of proper control groups, in order to provide more reliable data about the role of vitamin $\mathrm{C}$ in the cholesterol metabolism of humans.

\section{ACKNOWLEDGMENTS}

This work was supported by a grant from the Emil Aaltonen Foundation.

\section{REFERENCES}

1. Simonson, E. and Keys, A., Research in Russia on vitamins and atherosclerosis, Circulation, 24, 1239, 1961.

2. Turley, S. D., West, C. E., and Horton, B. J., The role of ascorbic acid in the regulation of cholesterol metabolism and in the pathogenesis of atherosclerosis, Atherosclerosis, 24, 1, 1976.

3. Ginter, E., Marginal vitamin C deficiency, lipid metabolism, and atherogenesis, Adv. Lipid Res., 16, 167, 1978.

4. Ginter, E., Regulation by ascorbic acid and other nutrients, in Cholesterol $7 \alpha$-hydroxylase, Fears, R. and Sabine, J., Eds., CRC Press, Boca Raton, 1986, 103.

5. Ginter, E., Bobek, P., and Ovecka, M., Model of chronic hypovitaminosis $\mathrm{C}$ in guinea-pigs, Int. J. Vitam. Nutr. Res., 38, 104, 1968.

6. Ginter, E., Bilisics, L., and Cerven, J., Cholesterol metabolism under conditions of acute and chronic vitamin C deficiency in guinea-pigs, Physiol. Bohemosl., 14, 466, 1965.

7. Ginter, E., Babala, J., and Cerven, J., The effect of chronic hypovitaminosis $\mathrm{C}$ on the metabolism of cholesterol and atherogenesis in guinea pigs, J. Atheroscler. Res., 10, 341, 1969.

8. Ginter, E., Ondreicka, R., Bobek, P., and Simko, $\mathbf{V}$., The influence of chronic vitamin $\mathrm{C}$ deficiency on fatty acid composition of blood serum, liver triglycerides and cholesterol esters in guinea pigs, $J$. Nutr., 99, 261, 1969.

9. Ginter, E., Ascorbic acid in cholesterol and bile acid metabolism, Ann. NY Acad. Sci., 258, 410, 1975.

10. Sulkin, N. M. and Sulkin, D. F., Tissue changes induced by marginal vitamin C deficiency, Ann. NY Acad. Sci., 258, 317, 1975.

11. Holloway, D. E., Peterson, F. J., Prigge, W. F., and Gebhard, R. L., Influence of dietary ascorbic acid upon enzymes of sterol biosynthesis in guinea pig, Biochem. Biophys. Res. Commun., 102, 1283, 1981.
12. Kato, N., Kawai, K., and Yoshida, A., Effect of dietary level of ascorbic acid on the growth, hepatic lipid peroxidation, and serum lipids in guinea pigs fed polychlorinated biphenyls, J. Nutr., 111, 1727, 1981.

13. Holloway, D. E. and Rivers, J. M., Long-term effects of inadequate and excessive dietary ascorbate on bile acid metabolism in the guinea pig, J. Nutr., 114, 1370, 1984.

14. Greene, Y. J., Harwood, H. J., and Stacpoole, P. W., Ascorbic acid regulation of 3-hydroxy-3methylglutaryl coenzyme A reductase activity and cholesterol synthesis in guinea pig liver, Biochim. Biophys. Acta, 834, 134, 1985.

15. Dasgupta, S. and Mukherjee, S., Effect of cadmium ions on ascorbate influence on cholesterolmetabolism in guinea pigs, Indian J. Exp. Biol., 26, 976, 1988.

16. Ginter, E., Bobek, P., Babala, J., and Barbierikova, E., The effect of ascorbic acid on the lipid metabolism of guinea pigs fed an atherogenic diet, Cor Vasa, 11, 65, 1969.

17. Hanck, A. and Weiser, H., Vitamin C and lipid metabolism, Int. J. Vitam. Nutr. Res., Suppl. 16, 67, 1977.

18. Nambisan, B. and Kurup, P. A., Ascorbic acid and glycosaminoglycan and lipid metabolism in guinea pigs fed normal and atherogenic diets, Atherosclerosis, 22, 447, 1975.

19. Ginter, E., Kosinova, A., Hudecova, A., and Mlynarcikova, U., Parabolic response of hepatic microsomal hydroxylating system and lipids to graded doses of ascorbic acid in guinea pigs on low and high $\alpha$-tocopherol intake, J. Nutr., 114, 485, 1984.

20. Kothari, L. K. and Sharma, P., Aggravation of cholesterol induced hyperlipidemia by chronic vitamin C deficiency, Acta Biol. Hung., 39, 49, 1988.

21. Satinder, Sarkar, A. K., Majumdar, S., and Chakravarti, R. N., Effect of ascorbic acid deficiency on the development of experimental atherosclerosis, Indian J. Med. Res., 86, 351, 1987.

22. Ha, T. Y., Otsuka, M., and Arakawa, N., The effect of graded doses of ascorbic acid on the tissue carnitine and plasma lipid concentrations, J. Nutr. Sci. Vitaminol., 36, 227, 1990.

23. Degkwitz, E. and Bödeker, R., Characterization of guinea pigs adapted to differently high vitamin C supplies, Z. Ernährungswiss., 29, 21, 1990.

24. Ginter, E., Cerven, J., Nemec, R., and Mikus, L., Lowered cholesterol catabolism in guinea pigs with chronic ascorbic acid deficiency, Am. J. Clin. Nutr., 24, 1238, 1971.

25. Ginter, E., Cholesterol: vitamin C controls its transformation to bile acids, Science, 179, 702, 1973.

26. Ginter, E., Nemec, R., Cerven, J., and Mikus, L., Quantification of lowered cholesterol oxidation in guinea pigs with latent vitamin C deficiency, Lipids, 8, 135, 1973 .

27. Hornig, D. and Weiser, H., Ascorbic acid and cho- 
lesterol: effect of graded oral intakes on cholesterol conversion to bile acids in guinea pigs, Experientia, 32, 687, 1976.

28. Ginter, E., Bobek, P., and Vargova, D., Tissue levels and optimum dosage of vitamin $\mathrm{C}$ in guinea pigs, Ann. Nutr. Metab., 23, 217, 1979.

29. Jenkins, S. A., Vitamin C status, serum cholesterol levels and bile composition in the pregnant guinea pig, Br. J. Nutr., 43, 95, 1980.

30. Holloway, D. E. and Rivers, J. M., Influence of chronic ascorbic acid deficiency and excessive ascorbic acid intake on bile acid metabolism and bile composition in the guinea pig, J. Nutr., 111, 412, 1981.

31. Holloway, D. E., Peterson, F. J., and Rivers, J. M., Effects of dietary ascorbic acid on bile acid metabolism in guinea pigs fed Krehl or Reid-Briggs diets, Nutr. Rep. Int., 25, 941, 1982.

32. Jenkins, S. A., Hypovitaminosis $\mathrm{C}$ and cholelithiasis in guinea pigs, Biochem. Biophys. Res. Commun., 77, 1030, 1977.

33. Jenkins, S. A., Biliary lipids, bile acids and gallstone formation in hypovitaminotic $\mathrm{C}$ guinea pigs, $\mathrm{Br} . \mathrm{J}$. Nutr., 40, 317, 1978.

34. Guchhait, R., Guha, B. C., and Ganguli, N. C., Metabolic studies on scorbutic guinea pigs, Biochem. J., 86, 193, 1963.

35. Harris, W. S., Kottke, B. A., and Subbiah, M. T., Bile acid metabolism in ascorbic acid-deficient guinea pigs, Am. J. Clin. Nutr., 32, 1837, 1979.

36. Bergman, F., Curstedt, T., Eriksson, H., Linden, W., and Sjövall, J., Gallstone formation in guinea pigs under different dietary conditions, Med. Biol., $59,92,1981$.

37. Fujinami, T., Okado, K., Senda, K., Sugimura, M., and Kishikawa, M., Experimental atherosclerosis with ascorbic acid deficiency, Jpn. Circ. J., 35, 1559,1971

38. Sakuma, N., Changes in serum lipoprotein in hypovitamin C atherosclerosis, Nagoya Med. J., 24, 37, 1979.

39. Yokota, F., Igarashi, Y., and Suzue, R., Hyperlipidemia in guinea-pigs induced by ascorbic acid deficiency, Atherosclerosis, 38, 249, 1981.

40. Ginter, E. and Nemec, R., Metabolism of [1${ }^{14} \mathrm{C}$ ]acetate in guinea pigs with chronic vitamin $\mathrm{C}$ hyposaturation, J. Atheroscler. Res., 10, 273, 1969.

41. Dulloo, R. M., Majumdar, S., Chakravarti, R. N., Mehta, S. K., and Mahmood, A., Effect of vitamin $\mathrm{C}$ deficiency in guinea pigs on intestinal functions and chemical composition of brush border membrane, Ann. Nutr. Metabl., 25, 213, 1981.

42. Weight, M. J., Compton-James, K., van Schalkwyk, D. J., and Seier, J. V., Cholesterolascorbic acid interactions in guinea pig liver homogenates, and in the in situ perfused liver: relationship between ascorbic acid status and cholesterol and bile acid synthesis from mevalonate, Int. J. Vitam. Nutr. Res., 52, 298, 1982.
43. Björkhem, I., Kallner, A., and Löf, A., The activity of HMB coenzyme A reductase in ascorbatedeficient and ascorbate supplemented guinea pigs, IRCS Med. Sci., 6, 230, 1978.

44. Harwood, H. J., Jr., Greene, Y. J., and Stacpoole, P. W., Inhibition of human leukocyte 3-hydroxy-3methylglutaryl coenzyme A reductase activity by ascorbic acid, J. Biol. Chem., 261, 7127, 1986.

45. Ginter, E., Cerven, J., and Mikus, L., The effect of chronic hypovitaminosis $\mathrm{C}$ on the absorption of cholesterol-4-C ${ }^{14}$ in guinea pigs, Physiol. Bohemosl., 18, 459, 1969.

46. Vlahcevic, Z. R., Heuman, D. M., and Hylemon, P. B., Regulation of bile acid synthesis, Hepatology, 13, 590, 1991.

47. Björkhem, I. and Kallner, A., Hepatic $7 \alpha$-hydroxylation of cholesterol in ascorbate-deficient and ascorbate-supplemented guinea pigs, J. Lipid Res., 17, 360, 1976

48. Peterson, F. J., Holloway, D. E., Duquette, P. H., and Rivers, J. M., Dietary ascorbic acid and hepatic mixed function oxidase activity in the guinea pig, Biochem. Pharmacol., 32, 91, 1983.

49. Ginter, E., Ozdin, L., and Nemec, R., Localization of the interference of ascorbic acid deficiency with bile acid biogenesis, Physiol. Bohemosl., 26, 353, 1977.

50. Kritchevsky, D., Tepper, S. A., and Story, J. A., Influence of vitamin $\mathrm{C}$ on hydroxylation and side chain oxidation of cholesterol in vitro, Lipids, 8, 482, 1973.

51. Sharma, P., Pramod, J., Sharma, P. K., Chaturvedi, S. K., and Kothari, L. K., Effect of vitamin $\mathrm{C}$ administration on serum and aortic lipid profile of guinea pigs, Indian J. Med. Res., 87, 283, 1988.

52. Larroya, S., George, M., Soni, G. L., Jethi, R. K., and Singh, R., Effect of megadoses of ascorbate with different dietary protein sources on lipid metabolism in guinea pigs fed on atherogenic diets, Indian $J$. Exp. Biol., 18, 1430, 1980.

53. Banerjee, S. and Singh, H. D., Cholesterol metabolism in scorbutic guinea pigs, J. Biol. Chem., 233, $336,1958$.

54. Willis, G. C., An experimental study of the intimal ground substance in atherosclerosis, Can. Med. Assoc. J., 69, 17, 1953.

55. Bolker, H. I., Fishman, S., Heard, R. D., O'Donnell, V. J., Webb, J. L., and Willis, G. C., The incorporation of acetate-1- $\mathrm{C}^{14}$ into cholesterol and fatty acids by surviving tissues of normal and scorbutic guinea pigs, J. Exp. Med., 103, 199, 1956.

56. Banerjee, S. and Bandyopadhyay, A., Plasma lipids in scurvy, Proc. Soc. Exp. Biol. Med., 112, 372, 1963.

57. Odumosu, A., How vitamin C, clofibrate and diosgenin control cholesterol metabolism in male guinea pigs, Int. J. Vitam. Nutr. Res., Suppl. 23, 187, 1982.

58. Stoecker, B. J. and Oladut, W. K., Effects of chro- 
mium and ascorbate deficiencies on glucose tolerance and serum cholesterol of guinea pigs, Nutr. Rep. Int., 32, 399, 1985 .

59. Phillips, W. E. J., Interrelationship of vitamins A and $\mathrm{C}$ on tissue ubiquinones and sterols of rats and guinea pigs, Can. J. Biochem., 45, 749, 1967.

60. Willis, G. C., The reversibility of atherosclerosis, Can. Med. Assoc. J., 77, 106, 1957.

61. Chakravarti, R. N., De, U. N., and Mukerji, B., Therapeutic effect of ascorbic acid and vitamin $\mathrm{B}_{12}$ in cholesterol atherosclerosis, Indian J. Med. Res., 45, 315, 1957.

62. Myasnikov, A. L., Influence of some factors on development of experimental cholesterol atherosclerosis, Circulation, 17, 99, 1958.

63. Zaitsev, V. F., Myasnikov, L. A., Kasatkina, L. V., Lobova, N. M., and Sukasova, T. I., The effect of ascorbic acid on experimental atherosclerosis, Cor Vasa, 6, 19, 1964.

64. Sokoloff, B., Hori, M., Saelhof, C. C., Wrzolek, T., and Imai, T., Aging, atherosclerosis and ascorbic acid metabolism, J. Am. Geriat. Soc., 14, 1239, 1966.

65. Hutagalung, R. I., Cromwell, G. L., Hays, V. W., and Chaney, C. H., Effect of dietary fat, protein, cholesterol and ascorbic acid on performance, serum and tissue cholesterol levels and serum lipid levels of swine, J. Anim. Sci., 29, 700, 1969.

66. Zohdy, A., Kassab, M., Tawab, S. A., Akkad, I. N., El-Din, A. K., and Ammar, E. M., The effect of prophylactic therapy with ascorbic acid, clofibrate and reserpine on the development of experimental atherosclerosis, J. Drug Res., 6, 109, 1974.

67. Jayakumari, N., Nampoothiri, V. K., Nambisan, B., and Kurup, P. A., Lowering of aortic cholesterol in hypercholesterolemic rats, Indian J. Exp. Biol., 16, 1289, 1978.

68. Slocum, M., Pond, W. G., and Walker, E. F., Effect of dietary ascorbic acid on serum cholesterol of young adult male rabbits fed a high cholesterol diet, Nutr. Rep. Int., 17, 191, 1978.

69. Sadava, D., Watumull, D., Sanders, K., and Downey, K., The effect of vitamin $\mathrm{C}$ on the rapid induction of aortic changes in rabbits, J. Nutr. Sci. Vitaminol., 28, 85, 1982.

70. Pool, W. R., Newmark, H. L., Dalton, C., Banziger, R. F., and Howard, A. N., Effect of biotin and ascorbic acid on the development of atherosclerosis in rabbits, Atherosclerosis, 14, 131, 1971.

71. Nambisan, B. and Kurup, P. A., The effect of massive doses of ascorbic acid and methionine on the levels of lipids and glycosaminoglycans in the aorta of weanling rats, Atherosclerosis, 19, 191, 1974.

72. Chen, L. H. and Thacker, R. R., Effects of dietary vitamin $\mathrm{E}$ and high supplementation of vitamin $\mathrm{C}$ on plasma glucose and cholesterol levels, Nutr. Res., 5, 527, 1985.

73. Holloway, D. E., Guiry, V. C., Holloway, B. A., and Rivers, J. M., Influence of dietary ascorbic acid on cholesterol $7 \alpha$-hydroxylase in the rat, Int. J. Vitam. Nutr. Res., 54, 333, 1984.

74. Horio, F., Ozaki, K., Oda, H., Makino, S., Hayashi, Y., and Yoshida, A., Effect of dietary ascorbic acid, cholesterol and PCB on cholesterol concentrations in serum and liver in a rat mutant unable to synthesize ascorbic acid, J. Nutr., 117, 1036, 1987.

75. Horio, F., Ozaki, K., Oda, H., Makino, S., Hayashi, Y., and Yoshida, A., Effect of dietary ascorbic acid, cholesterol and PCB on cholesterol and bile acid metabolism in a rat mutant unable to synthesize ascorbic acid, J. Nutr., 119, 409, 1989.

76. Uchida, K., Nomura, Y., Takase, H., Tasaki, T., Seo, S., Hayashi, Y., and Takeuchi, N., Effect of vitamin $\mathrm{C}$ depletion on serum cholesterol and lipoprotein levels in ODS (od/od) rats unable to synthesize ascorbic acid, J. Nutr., 120, 1140, 1990.

77. Kono, K., Hayakawa, M., Asai, K., and Kuzuya, F., Cholesterol metabolism in inherently scorbutic rats (ODS rats), J. Nutr. Sci. Vitaminol., 34, 35, 1988.

78. Ginter, E., Effect of dietary cholesterol on vitamin C metabolism in laboratory animals, Acta Med. Acad. Sci. Hung., 27, 23, 1970.

79. Ginter, E. and Zloch, Z., Raised ascorbic acid consumption in cholesterol-fed guinea pigs, Int. J. Vitam. Nutr. Res., 42, 72, 1972.

80. Pauling, L., Orthomolecular psychiatry, Science, 160, 265, 1968.

81. Pauling, L., Evolution and the need for ascorbic acid, Proc. Natl. Acad. Sci. U.S.A., 67, 1643, 1970.

82. Conney, A. H., Bray, G. A., Evans, C., and Burns, J. J., Metabolic interactions between L-ascorbic acid and drugs, Ann. NY Acad. Sci., 92, 115, 1961.

83. Touster, O. and Hollmann, S., Nutritional and enzymatic studies on the mechanism of stimulation of ascorbic acid synthesis by drugs and carcinogenic hydrocarbons, Ann. NY Acad. Sci., 92, 318, 1961.

84. Nambisan, B. and Kurup, P. A., Ascorbic acid metabolism in rats fed high fat cholesterol diet, Atherosclerosis, 25, 63, 1976.

85. Novitskii, A. A., Mechanism likely to cause resistance to alimentary hypercholesterolaemia in rabbits, Cor Vasa, 13, 280, 1971.

86. Tall, A. R., Plasma high density lipoproteins. Metabolism and relationship to atherogenesis, J. Clin. Invest., 86, 379, 1990.

87. Goldberg, I. J., Blaner, W. S., Vanni, T. M., Moukides, M., and Ramakrishnan, R., Role of lipoprotein lipase in the regulation of high density lipoprotein apolipoprotein metabolism, J. Clin. Invest., 86, 463, 1990.

88. Ginter, E. and Jurcovicova, M., Chronic vitamin $\mathrm{C}$ deficiency lowers fractional catabolic rate of lowdensity lipoproteins in guinea pigs, Ann. NY Acad. Sci., 498, 473, 1987.

89. Horio, F., Takahashi, N., Makino, S., Hayashi, Y., and Yoshida, A., Ascorbic acid deficiency el- 
evates serum level of LDL-cholesterol in a rat mutant unable to synthesize ascorbic acid, J. Nutr. Sci. Vitaminol., 37, 63, 1991.

90. Aulinskas, T. H., Westhuyzen, D. R., and Coetzee, G. A., Ascorbate increases the number of low density lipoprotein receptors in cultured arterial smooth muscle cells, Atherosclerosis, 47, 159, 1983.

91. Mbewu, A. D. and Durrington, P. N., Lipoprotein(a): structure, properties and possible involvement in thrombogenesis and atherogenesis, Atherosclerosis, 85, 1, 1990.

92. Rath, M. and Pauling, L., Immunological evidence for the accumulation of lipoprotein(a) in the atherosclerotic lesion of the hypoascorbemic guinea pig, Proc. Natl. Acad. Sci. U.S.A., 87, 9388, 1990.

93. Rath, M. and Pauling, L., Solution to the puzzle of human cardiovascular disease: its primary cause is ascorbate deficiency leading to the deposition of lipoprotein(a) and fibrinogen/fibrin in the vascular wall, J. Orthomolecular Med., 6, 125, 1991.

94. Steinberg, D., Parthasarathy, S., Carew, T. E., Khoo, J. C., and Witztum, J. L., Beyond cholesterol. Modifications of low-density lipoprotein that increase its atherogenicity, N. Engl. J. Med., 320, 915, 1989.

95. Halliwell, B., Free radicals, reactive oxygen species and human disease: a critical evaluation with special reference to atherosclerosis, Br. J. Exp. Pathol., 70, $737,1989$.

96. Frei, B., Stocker, R., and Ames, B. N., Antioxidant defenses and lipid peroxidation in human blood plasma, Proc. Natl. Acad. Sci. U.S.A., 85, 9748, 1988.

97. Frei, B., England, L., and Ames, B. N., Ascorbate is an outstanding antioxidant in human blood plasma, Proc. Natl. Acad. Sci. U.S.A., 86, 6377, 1989.

98. Halliwell, B. and Gutteridge, J. M. C., The antioxidants of human extracellular fluids, Arch. Biochem. Biophys., 280, 1, 1990.

99. Niki, E., Vitamin $\mathrm{C}$ as an antioxidant, World Rev. Nutr. Diet., 64, 1, 1991.

100. Packer, J. E., Slater, T. F., and Willson, R. L., Direct observation of a free radical interaction between vitamin E and vitamin C, Nature, 278, 737, 1979

101. Gey, K. F., On the antioxidant hypothesis with regard to arteriosclerosis, Bibl. Nutr. Dieta, 37, 53, 1986.

102. Esterbauer, H., Striegl, G., Puhl, H., Oberreither, S., Rotheneder, M., El-Saadani, M., and Jürgens, G., The role of vitamin $\mathrm{E}$ and carotenoids in preventing oxidation of low density lipoproteins, Ann. NY Acad. Sci., 570, 254, 1989.

103. Jialal, I., Vega, G. L., and Grundy, S. M., Physiologic levels of ascorbate inhibit the oxidative modification of low density lipoprotein, Atherosclerosis, $82,185,1990$.

104. Sato, K., Niki, E., and Shimasaki, H., Free radicalmediated chain oxidation of low density lipoprotein and its synergistic inhibition by vitamin $E$ and vitamin C, Arch. Biochem. Biophys., 279, 402, 1990

105. Jialal, I. and Grundy, S. M., Preservation of the endogenous antioxidants in low density lipoprotein by ascorbate but not probucol during oxidative modification, J. Clin. Invest., 87, 597, 1991

106. Kunert, K. J. and Tappel, A. L., The effect of vitamin $\mathrm{C}$ on in vivo lipid peroxidation in guinea pigs as measured by penthane and ethane production, Lipids, 18, 271, 1983 .

107. Dillard, C. J., Downey, J. E., and Tappel, A. L., Effect of antioxidants on lipid peroxidation in ironloaded rats, Lipids, 19, 127, 1984.

108. Wartanowicz, M., Panczenko-Kresowska, B. Ziemlanski, S., Kowalska, M., and Okolska, G., The effect of $\alpha$-tocopherol and ascorbic acid on the serum lipid peroxide level in elderly people, Ann. Nutr. Metab., 28, 186, 1984.

109. Bobek, P., Ginter, E., Ozdin, L., and Mikus, L., The effect of chronic marginal vitamin $\mathrm{C}$ deficiency on the rate of secretion and the removal of plasma triglycerides in guinea pigs, Physiol. Bohemosl., 29, 337, 1980 .

110. Bobek, P. and Ginter, E., Serum triglycerides and post-heparin lipolytic activity in guinea-pigs with latent vitamin C deficiency, Experientia, 34, 1554, 1978.

111. Bobek, P., Ginter, E., Ozdin, L., Poledne, R., and Potucek, J., Effect of long-term marginal vitamin $\mathrm{C}$ deficiency on plasma triglyceride kinetics in guinea pigs, Biomed. Biochim. Acta, 42, 413, 1983.

112. Hughes, R. E., Hurley, R. J., and Jones, E., Dietary ascorbic acid and muscle carnitine in guinea pigs, Br. J. Nutr., 43, 385, 1980.

113. Kotzé, J. P., Menne, I. V., Spies, J. H., and De Klerk, W. A., Effect of ascorbic acid on serum lipid levels and depot cholesterol of the baboon, S. Afr. Med. J., 49, 906, 1975.

114. Banerjee, S. and Bandyopadhyay, A., Plasma lipids in ascorbic acid-deficient rhesus monkeys, Am. J. Physiol., 208, 329, 1965.

115. Machlin, L. J., Garcia, F., Kuenzig, W., Richter, C. B., Spiegel, H. E., and Brin, M., Lack of antiscorbutic activity of ascorbate 2-sulphate in the rhesus monkey, Am. J. Clin. Nutr., 29, 825, 1976.

116. Eckel, R. H., Lipoprotein lipase. A multifunctional enzyme relevant to common metabolic diseases, $N$. Engl. J. Med., 320, 1060, 1989.

117. Kotzé, J. P. and Spies, J. H., The effect of ascorbic acid on the activity of lipoprotein lipase in the baboon, S. Afr. Med. J., 50, 1760, 1976.

118. Hulse, J. D., Ellis, S. R., and Henderson, L. M. Carnitine biosynthesis, J. Biol. Chem., 253, 1654, 1978.

119. Englard, S. and Seifter, S., The biochemical functions of ascorbic acid, Annu. Rev. Nutr., 6, 365, 1986

120. Carnitine deficiency, Lancet, 335, 631, 1990. 
121. Goa, K. L. and Brogden, R. N., L-Carnitine, Drugs, 34, 1, 1987.

122. Ciman, M., Rizzoli, V., and Siliprandi, N., Deficiency of carnitine induced by scurvy, IRCS Med. Sci., 7, 253, 1979.

123. Nelson, P. J., Pruitt, R. E., Henderson, L. L., Jenness, R., and Henderson, L. M., Effect of ascorbic acid deficiency on the in vivo synthesis of carnitine, Biochim. Biophys. Acta, 672, 123, 1981.

124. Sandor, A., Kispal, G., Kerner, J., and Alkonyi, I., Combined effect of ascorbic acid deficiency and underfeeding on the hepatic carnitine level in guinea pigs, Experientia, 39, 512, 1983.

125. Dunn, W. A., Rettura, G., Seifter, E., and Englard, S., Carnitine biosynthesis from butyrobetaine and from exogenous protein-bound 6- $\mathrm{N}$-trimethyl-L-lysine by the perfused guinea pig liver, $J$. Biol. Chem., 259, 10764, 1984.

126. Thoma, W. J. and Henderson, L. M., Effect of vitamin $\mathrm{C}$ deficiency on hydroxylation of trimethylaminobutyrate to carnitine in the guinea pig, Biochim. Biophys. Acta, 797, 136, 1984.

127. Jones, E. and Hughes, R. E., Influence of oral carnitine on the body weight and survival time of avitaminotic-C guinea pigs, Nutr. Rep. Int., 25, 201, 1982.

128. Bronte-Stewart, B., Roberts, B., and Wells, V. M., Serum cholesterol in vitamin $\mathrm{C}$ deficiency in man, Br. J. Nutr., 17, 61, 1963.

129. Hodges, R. E., Hood, J., Canham, J. E., Sauberlich, H. E., and Baker, E. M., Clinical manifestations of ascorbic acid deficiency in man, Am. J. Clin. Nutr., 24, 432, 1971.

130. Gatenby Davies, J. D. and Newson, J., Ascorbic acid and cholesterol levels in pastoral peoples in Kenya, Am. J. Clin. Nutr., 27, 1039, 1974.

131. Vitamin-C requirement of human adults. Experimental study of vitamin-C deprivation in man, Lancet, 1, 853, 1948.

132. Shafar, J., Rapid reversion of electrocardiographic abnormalities after treatment in two cases of scurvy, Lancet, 2, 176, 1967.

133. Sament, S., Cardiac disorders in scurvy, N. Engl. J. Med., 282, 282, 1970.

134. Singh, D. and Chan, W., Cardiomegaly and generalized oedema due to vitamin C deficiency, Singapore Med. J., 15, 60, 1974.

135. Willis, G. C., Light, A. W., and Gow, W. S., Serial arteriography in atherosclerosis, Can. Med. Assoc. J., 71, 562, 1954.

136. Banerjee, S. and Bal, H., Biochemical changes in scorbutic rhesus monkeys, Indian J. Med. Res., 47, 663, 1959.

137. McIntosh, G. H., Richmond, W., and Himsworth, R. L., Vitamin $\mathrm{C}$ deficiency and hypercholesterolaemia in marmoset monkeys, Nutr. Rep. Int., 23, 237, 1981

138. Weight, M. J., Kotzé, J. P., De Klerk, W. A., and Weight, N., The effect of dietary ascorbic acid on cholesterol biosynthesis in vitro, Int. J. Biochem., 5, 287, 1974.

139. Kotzé, J. P., The effects of vitamin C on lipid metabolism, S. Afr. Med. J., 49, 1651, 1975.

140. Pedersen, L., Biliary lipids during vitamin C feeding in healthy persons, Scand. J. Gastroent., 10, 311, 1975.

141. Kallner, A., Serum bile acids in man during vitamin C supplementation and restriction, Acta Med. Scand., 202, 283, 1977.

142. Duane, W. C. and Hutton, S. W., Lack of effect of experimental ascorbic acid deficiency on bile acid metabolism, sterol balance, and biliary lipid composition in man, J. Lipid Res., 24, 1186, 1983.

143. Anderson, T. W., Reid, D. B., and Beaton, G. H., Vitamin C and serum-cholesterol, Lancet, 2, 876, 1972.

144. Crawford, G. P. M., Warlow, C. P., Bennett, B., Dawson, A. A., Douglas, A. S., Kerridge, D. F., and Ogston, D., The effect of vitamin C supplements on serum cholesterol, coagulation, fibrinolysis and platelet adhesiveness, Atherosclerosis, 21, 451, 1975.

145. Menne, I. V., Grey, P. C., Kotzé, J. P., Sommers, D. K., Brown, J. M., and Spies, J. H., Ascorbic acid and blood lipid and uric acid levels of students, S. Afr. Med. J., 49, 2225, 1975.

146. Horsey, J., Livesley, B., and Dickerson, J. W. T., Ischaemic heart disease and aged patients: effects of ascorbic acid on lipoproteins, J. Hum. Nutr., 35, 53, 1981.

147. Johnson, G. E. and Obenshain, S. S., Nonresponsiveness of serum high-density liporpotein-cholesterol to high dose ascorbic acid administration in normal men, Am. J. Clin. Nutr., 34, 2088, 1981.

148. Joshi, V. D., Joshi, L. N., and Gokhale, L. V., Effect of ascorbic acid on total and high density lipoprotein cholesterol of plasma in normal human subjects, Indian J. Physiol. Pharmacol., 25, 348, 1981.

149. Khan, A. R. and Seedarnee, F. A., Effect of ascorbic acid on plasma lipids and lipoproteins in healthy young women, Atherosclerosis, 39, 89, 1981.

150. Buzzard, I. M., McRoberts, M. R., Driscoll, D. L., and Bowering, J., Effect of dietary eggs and ascorbic acid on plasma lipis and lipoprotein cholesterol levels in healthy young men, Am. J. Clin. Nutr., 36, 94, 1982.

151. Sokoloff, B., Hori, M., Saelhof, C., McConnell, B., and Imai, T., Effect of ascorbic acid on certain blood fat metabolism factors in animals and man, $J$. Nutr., 91, 107, 1967.

152. Spittle, C. R., Atherosclerosis and vitamin C, Lancet, 2, 1280, 1971.

153. Hanck, A. B., Plasma cholesterol level in healthy subjects and the influence of high doses of ascorbic acid (in German), Z. Ernährungswiss., 12, 152, 1973.

154. Ginter, E., Cerna, O., Budlovsky, J., Balaz, V., Hruba, F., Roch, V., and Sasko, E., Effect of ascorbic acid on plasma cholesterol in humans in a 
long-term experiment, Int. J. Vitam. Nutr. Res., 47, 123, 1977.

155. Kothari, L. K. and Jain, K., Effect of vitamin C administration on blood cholesterol level in man, Acta Biol. Acad. Sci. Hung., 28, 111, 1977.

156. Vijayakumar, T. and Vasudevan, D. M., Effect of ascorbic acid administration on glucose tolerance and serum cholesterol in normal and in diabetic subjects, Indian Med. Gaz., 114(3), 96, 1980.

157. Fidanza, A., Audisio, M., and Mastroiacovo, P., Vitamin C and cholesterol, Int. J. Vitam. Nutr. Res., Suppl. 23, 153, 1982.

158. Dobson, H. M., Muir, M. M., and Hume, R., The effect of ascorbic acid on the seasonal variations in serum cholesterol levels, Scott. Med. J., 29, 176, 1984.

159. Koh, E. T., Effect of vitamin C on blood parameters of hypertensive subjects, J. Okla. State Med. Assoc., 77, 177, 1984.

160. Burr, M. L., Bates, C. J., Goldberg, G., and Butland, B. K., Vitamin $\mathrm{C}$ and cholesterol in the elderly, Hum. Nutr. Clin. Nutr., 39C, 387, 1985.

161. Erden, F., Gulenc, S., Torun, M., Kocer, Z., Simsek, B., and Nebioglu, S., Ascorbic acid effect on some lipid fractions in human beings, Acta Vitaminol. Enzymol., 7, 131, 1985.

162. Aro, A., Kyllästinen, M., Kostiainen, E., Gref, C. G., Elfving, S., and Uusitalo, U., No effect on serum lipids by moderate and high doses of vitamin $\mathrm{C}$ in elderly subjects with low plasma ascorbic acid levels, Ann. Nutr. Metab., 32, 133, 1988.

163. O'Brien, B. C. and McMurray, D. N., Human plasma lipid and immunologic responses to eggs and ascorbic acid, Nutr. Res., 8, 353, 1988.

164. Salonen, J. T., Salonen, R., Seppänen, K., RintaKiikka, S., Kuukka, M., Korpela, H., Alfthan, G., Kantola, M., and Schalch, W., Effects of antioxidant supplementation on platelet function: a randomized pair-matched, placebo-controlled, doubleblind trial in men with low antioxidant status, Am. J. Clin. Nutr., 53, 1222, 1991.

165. Ginter, E., Kajaba, I., and Nizner, O., The effect of ascorbic acid on cholesterolemia in healthy subjects with seasonal deficit of vitamin C, Nutr. Metab., $12,76,1970$.

166. Peterson, V. E., Crapo, P. A., Weininger, J., Ginsberg, H., and Olefsky, J., Quantification of plasma cholesterol and triglyceride levels in hypercholesterolemic subjects receiving ascorbic acid supplements, Am. J. Clin. Nutr., 28, 584, 1975.

167. Ginter, E., Zdichynec, B., Holzerova, O., Ticha, E., Kobza, R., Koziakova, M., Cerna, O., Ozdin, L., Hruba, F., Novakova, V., Sasko, E., and Gaher, M., Hypocholesterolemic effect of ascorbic acid in maturity-onset diabetes mellitus, Int. J. Vitam. Nutr. Res., 48, 368, 1978.

168. Ginter, E., Kubec, F. J., Vozar, J., and Bobek, P., Natural hypocholesterolemic agent: pectin plus ascorbic acid, Int. J. Vitam. Nutr. Res., 49, 406, 1979.

169. Bordia, A. K., The effect of vitamin C on blood lipids, fibrinolytic activity and platelet adhesiveness in patients with coronary artery disease, Atherosclerosis, 35, 181, 1980.

170. Bishop, N., Schorah, C. J., and Wales, J. K., The effect of vitamin C supplementation on diabetic hyperlipidaemia, Diabetic Med., 2, 121, 1985.

171. Gulenc, S. and Nebioglu, S., Serum triglyceride, total cholesterol and HDL-cholesterol levels in smoking volunteers taking ascorbic acid orally (in Turkish), FABAD J. Pharm. Sci., 13, 493, 1988.

172. Ginter, E., Disorders of cholesterol metabolism in marginal vitamin $\mathrm{C}$ deficiency and the problem of optimum ascorbic acid intake, Bibl. Nutr. Dieta, 44, 85, 1989.

173. Samuel, P. and Shalchi, O. B., Effect of vitamin $\mathrm{C}$ on serum cholesterol in patients with hypercholesterolemia and arteriosclerosis, Circulation, 29, 24, 1964.

174. Filho, R. L., Lima, M., Kneipp, R., Cunha, L., and Ogliari, M., Serum cholesterol levels and ascorbic acid (in Portuguese), Folha Med., 77, 451, 1978.

175. Heine, H. and Norden, C., Vitamin C therapy in hyperlipoproteinemia, Int. J. Vitam. Nutr. Res., Suppl. 19, 45, 1979.

176. Wahlberg, G. and Walldius, G., Lack of effect of ascorbic acid on serum lipoprotein concentrations in patients with hypertriglyceridaemia, Atherosclerosis, 43, 283, 1982.

177. Mamianetti, A., Vescina, M. C., Matejka, M. A., Alvarez, O., Dameno, E., and Carducci, C. N., The effect of ascorbic acid on the biliary lipids of lithiasic patients (in Spanish), Prensa Med. Argent., 75, 346, 1988.

178. Martin, M. J., Hulley, S. B., Browner, W. S., Kuller, L. H., and Wentworth, D., Serum cholesterol, blood pressure, and mortality: implications from a cohort of 361662 men, Lancet, 2, 933, 1986

179. Sherwin, R. W., Wentworth, D. N., Cutler, J. A., Hulley, S. B., Kuller, L. H., and Stamler, J., Serum cholesterol levels and cancer mortality in 361 662 men screened for the multiple risk factor intervention trial, JAMA, 257, 943, 1987.

180. Iso, H., Jacobs, D. R., Wentworth, D., Neaton, J. D., and Cohen, J. D., Serum cholesterol levels and six-year mortality from stroke in 350,977 men screened for the multiple risk factor intervention trial, N. Engl. J. Med., 320, 904, 1989.

181. Ginter, E., Pretreatment serum-cholesterol and response to ascorbic acid, Lancet, 2, 958, 1979.

182. Garry, P. J., Vanderjagt, D. J., and Hunt, W. C., Ascorbic acid intakes and plasma levels in healthy elderly, Ann. NY Acad. Sci., 498, 90, 1987.

183. National Research Council, Recommended Dietary Allowances, 10th ed., National Academy Press, Washington, DC, 1989, 115. 
184. Williams, R. J. and Deason, G., Individuality in vitamin C needs, Proc. Natl. Acad. Sci. U.S.A., 57, 1638, 1967.

185. Yew, M. L. S., "Recommended Daily Allowances", for vitamin C, Proc. Natl. Acad. Sci. U.S.A., 70, 969, 1973.

186. Keys, A., Serum cholesterol response to dietary cholesterol, Am. J. Clin. Nutr., 40, 351, 1984; 44, 309, 1986.

187. Stamler, J. and Shekelle, R., Dietary cholesterol and human coronary heart disease, Arch. Pathol. Lab. Med., 112, 1032, 1988.

188. Anderson, J. W., Deakins, D. A., Floore, T. L., Smith, B. M., and Whitis, S. E., Dietary fiber and coronary heart disease, Crit. Rev. Food Sci. Nutr., 29, 95, 1990.

189. Grundy, S. M. and Denke, M. A., Dietary influences on serum lipids and lipoproteins, J. Lipid Res. 31, 1149, 1990

190. Brown, M. S. and Goldstein, J. L., A receptormediated pathway for cholesterol homeostasis, Sci ence, 232, 34, 1986.

191. Austin, M. A., King, M. C., Bawol, R. D., Hulley, S. B., and Friedman, G. D., Risk factors for coronary heart disease in adult female twins, Am. $J$. Epidemiol., 125, 308, 1987.

192. Zilva, J. F. and Pannall, P. R., Clinical Chemistry in Diagnosis and Treatment, 3rd ed., Lloyd-Luke, London, 1979, 472.

193. Castelli, W. P., Garrison, R. J., Wilson, P. W., Abbott, R. D., Kalousdian, S., and Kannel, W. B. Incidence of coronary heart disease and lipoprotein cholesterol levels. The Framingham study, JAMA, 256, 2835, 1986.

194. Gordon, D. J. and Rifkind, B. M., High-density lipoprotein - the clinical implications of recent studies, N. Engl. J. Med., 321, 1311, 1989.

195. Austin, M. A., Plasma triglyceride and coronary heart disease, Arterioscler. Thromb., 11, 2, 1991.

196. Geoly, K. L. and Diamond, L. H., Ascorbic acid and hypertriglyceridemia, Ann. Intern. Med., 93, 511, 1980.

197. Davies, H. E. F., Gruffudd, S., Hughes, R. E., and Jones, E., Ascorbic acid and carnitine in man, Nutr. Rep. Int., 36, 941, 1987.

198. Jacob, R. A. and Pianalto, F. S., Effect of experimental ascorbate depletion on plasma and urinary carnitine levels in healthy men, Clin. Chem., 37, 984, 1991.

199. Masek, J., A study of cholesterolaemia in different groups of the population (in French), Nutr. Dieta, 2, 193,1960

200. Cheraskin, E. and Ringsdorf, W. M., A lingual vitamin $\mathrm{C}$ test: relationship of nonfasting serum cholesterol and vitamin C state, Int. J. Vitam. Nutr. Res., 38, 415, 1968.

201. Kajaba, I. and Bucko, A., Health and nutritional status of children in an industrialized and agricultural area of Eastern Slovakia, Rev. Czechosl. Med., 14, $180,1968$.

202. Elwood, P. C., Hughes, R. E., and Hurley, R.J., Ascorbic acid and serum-cholesterol, Lancet, 2, 1197, 1970.

203. Jain, K., Kothari, L. K., Chaturvedi, S. K., Jain, T. P., and Maitrya, B. B., Age, serum cholesterol and vitamin C, Asian Med. J., 19, 709, 1976.

204. Bates, C. J., Mandal, A. R., and Cole, T. J., HDL cholesterol and vitamin-C status, Lancet, 2, 611, 1977.

205. Cerna, O. and Ginter, E., Blood lipids and vitaminC status, Lancet, 1, 1055, 1978.

206. Koh, E. T. and Stewart, T., Interrelationship among the blood components and anthropometric measurements, Nutr. Rep. Int., 18, 539, 1978.

207. Bates, C. J., Burr, M. K., and Leger, A. S., Vitamin $\mathrm{C}$, high density lipoproteins and heart disease in elderly subjects, Age Ageing, 8, 177, 1979.

208. Olusi, S. O., Ojutiku, O. O., Jessop, W. J., and Iboko, M. I., Plasma and white blood cell ascorbic acid concentrations in patients with bronchial asthma, Clin. Chim. Acta, 92, 161, 1979.

209. Koh, E. T. and Chi, M. S., Relationship of serum vitamin $\mathrm{C}$ and globulin fractions with anthropometric measurements in adults, Nutr. Rep. Int., 21, 537, 1980.

210. Dwyer, T., Calvert, G. D., Baghurst, K. I., and Leitch, D. R., Diet, other lifestyle factors and HDL cholesterol in a population of Australian male service recruits, Am. J. Epidemiol., 114, 683, 1981.

211. Burr, M. L., Bates, C. J., Millbank, J. E., and Yarnell, J. W. G., The relationship between plasma ascorbate and lipid concentrations in fasting men, Hum. Nutr. Clin. Nutr., 36C, 135, 1982.

212. Burr, M. L., Bates, C. J., Sweetnam, P. M., and Barasi, M. E., Plasma ascorbate and HDL-cholesterol in women, Hum. Nutr. Clin. Nutr., 36C, 399, 1982.

213. Greco, A. M. and Rocca, L. L., Correlation between chronic hypovitaminosis $\mathrm{C}$ in old age and plasma levels of cholesterol and triglycerides, Int. J. Vitam. Nutr. Res., Suppl. 23, 129, 1982.

214. Hooper, P. L., Hooper, E. M., Hunt, W. C., Garry, P. J., and Goodwin, J. S., Vitamins, lipids and lipoproteins in a healthy elderly population, Int. J. Vitam. Nutr. Res., 53, 412, 1983.

215. Saha, N. and Tan, P. Y., Serum vitamin C and total cholesterol levels in healthy adults, Singapore Med. J., 24, 150, 1983.

216. Church, J. P., Judd, J. T., Young, C. W., Kelsay, J. L., and Kim, W. W., Relationships among dietary constituents and specific serum clinical components of subjects eating self-selected diets, Am. J. Clin. Nutr., 40, 1338, 1984.

217. Yoshioka, M., Matsushita, T., and Chuman, Y., Inverse association of serum ascorbic acid level and blood pressure or rate of hypertension in male adults aged 30 to 39 years, Int. J. Vitam. Nutr. Res., 54, 343,1984 
218. Mayet, F. H. G., Sewdarsen, M., and Reinach, S. G., Ascorbic acid and cholesterol levels in patients with diabetes mellitus and coronary artery disease, S. Afr. Med. J., 70, 661, 1986.

219. Jacques, P. F., Hartz, S. C., McGandy, R. B., Jacob, R. A., and Russell, R. M., Ascorbic acid, $\mathrm{HDL}$, and total plasma cholesterol in the elderly, $J$. Am. Coll. Nutr., 6, 169, 1987.

220. Kothari, L. K., Pramod, J., Sharma, P., and Chaturvedi, S. K., Influence of age and vitamin C status on serum cholesterol, Int. J. Epidemiol., 17, 929, 1988.

221. Salonen, J. T., Salonen, R., Seppänen, K., Kantola, M., Parviainen, M., Alfthan, G., Mäenpää, P. H., Taskinen, E., and Rauramaa, R., Relationship of serum selenium and antioxidants to plasma lipoproteins, platelet aggregability and prevalent ischemic heart disease in Eastern Finnish men, Atherosclerosis, 70, 155, 1988

222. Dallal, G. E., Choi, E., Jacques, P., Schaefer, E. J., and Jacob, R. A., Ascorbic acid, HDL cholesterol, and apolipoprotein A-I in an elderly Chinese population in Boston, J. Am. Coll. Nutr., 8, 69, 1989.

223. Itoh, R., Yamada, K., Oka, J., Echizen, H., Suyama, Y., and Murakami, K., Serum ascorbic acid and HDL cholesterol in a healthy elderly Japanese population, Int. J. Vitam. Nutr. Res., 60, 360, 1990.

224. Riemersma, R. A., Oliver, M., Elton, R. A., Alfthan, G., Vartiainen, E., Salo, M., Rubba, P., Mancini, M., Georgi, H., Vuilleumier, J. P., and Gey, K. F., Plasma antioxidants and coronary heart disease: vitamins $\mathrm{C}$ and $\mathrm{E}$, and selenium, Eur. J. Clin. Nutr., 44, 143, 1990.

225. Koh, E. T., Selected blood components and urinary $\mathrm{B}$ vitamins as related to age and sex of black population in Southwest Mississippi, Am. J. Clin. Nutr., 33, 670, 1980.

226. Mogadam, M., Ahmed, S. W., Mensch, A. H., and Godwin, I. D., Within-person fluctuations of serum cholesterol and lipoproteins, Arch. Intern. Med., 150, 1645, 1990.

227. Davis, C. E., Rifkind, B. M., Brenner, H., and Gordon, D. J., A single cholesterol measurement underestimates the risk of coronary heart disease, JAMA, 264, 3044, 1990

228. Sempos, C. T., Johnson, N. E., Smith, E. L., and Gilligan, C., Effects of intraindividual and interindividual variation in repeated dietary records, Am. J. Epidemiol., 121, 120, 1985

229. Jacobs, D. R., Jr., Anderson, J. T., and Blackburn, H., Diet and serum cholesterol. Do zero correlations negate the relationship?, Am. J. Epidemiol., 110, 77, 1979.

230. Knox, E. G., Ischaemic-heart-disease mortality and dietary intake of calcium, Lancet, 1, 1465, 1973.

231. Armstrong, B. K., Mann, J. I., Adelstein, A. M. and Eskin, F., Commodity consumption and is- chemic heart disease mortality, with special reference to dietary practices, J. Chron. Dis., 28, 455, 1975.

232. Gey, K. F., Puska, P., Jordan, P., and Moser, U. K., Inverse correlation between plasma vitamin $\mathrm{E}$ and mortality from ischemic heart disease in crosscultural epidemiology, Am. J. Clin. Nutr., 53, 326S, 1991.

233. Crombie, I. K., Smith, W. C., Tavendale, R., and Tunstall-Pedoe, H., Geographical clustering of risk factors and lifestyle for coronary heart disease in the Scottish Heart Health Study, Br. Heart J., 64, 199, 1990.

234. Ramirez, J. and Flowers, N. C., Leukocyte ascorbic acid and its relationship to coronary artery disease in man, Am. J. Clin. Nutr., 33, 2079, 1980.

235. Riemersma, R. A., Wood, D. A., MacIntyre, C. C., Elton, R. A., Gey, K. F., and Oliver, M. F., Risk of angina pectoris and plasma concentrations of vitamins A, C, and E and carotene, Lancet, 337, 1,1991 .

236. Ginter, E., Decline of coronary mortality in United States and vitamin C, Am. J. Clin. Nutr., 32, 511 , 1979.

237. Verlangieri, A. J., Kapeghian, J. C., el-Dean, S., and Bush, M., Fruit and vegetable comsumption and cardiovascular mortality, Med. Hypotheses, 16, 7, 1985.

238. Bulpitt, C. J., Vitamin C and blood pressure, $J$. Hypertens., 8, 1071, 1990

239. Hemilä, H., Vitamin $C$ and lowering of blood pressure: need for intervention trials?, J. Hypertens., 9, 1076, 1991.

240. Osilesi, O., Trout, D. L., Ogunwole, J. O., and Glover, E. E., Blood pressure and plasma lipids during ascorbic acid supplementation in borderline hypertensive and normotensive adults, Nutr. Res., 11, 405, 1991

241. Hemilä, H., Nutritional need versus optimal intake, Med. Hypotheses, 14, 135, 1984.

242. Hemilä, H., A reevaluation of nutritional goals not just deficiency counts, Med. Hypotheses, 20, 17, 1986.

243. Levine, M., New concepts in the biology and biochemistry of ascorbic acid, N. Engl. J. Med., 314, 892, 1986.

244. Levine, M. and Hartzell, W., Ascorbid acid: the concept of optimum requirements, Ann. NY Acad. Sci., 498, 424, 1987.

245. Pauling, L., How to Live Longer and Feel Better, Freeman, New York, 1986.

246. Ginter, E., Ascorbic acid in cholesterol metabolism and in detoxification of xenobiotic substances: problem of optimum vitamin C intake, Nutrition, 5, 369, 1989.

247. Hemilä, H., Is there a biochemical basis for "nutrient need"?, Trends Food Sci. Technol., 2, 73, 1991.

248. Bourne, G. H., Vitamin C and immunity, Br. $J$. Nutr., 2, 341, 1949. 
249. Eaton, S. B. and Konner, M., Paleolithic nutrition, N. Engl. J. Med., 312, 283, 1985.

250. Chakrabarti, B. and Banerjee, S., Dehydroascorbic acid level in blood of patients suffering from various infectious diseases, Proc. Soc. Exp. Biol. Med., 88, 581, 1955.

251. Chope, H. D. and Breslow, L., Nutritional status of the aging, Am. J. Publ. Health, 46, 61, 1956.

252. Milner, G., Ascorbic acid in chronic psychiatric patients - a controlled trial, Br. J. Psychiat., 109, 294, 1963.

253. Greenwood, J., Optimum vitamin $\mathrm{C}$ intake as a factor in the preservation of disc integrity, Med. Ann. Distr. Columbia, 33, 274, 1964.

254. Klenner, F. R., Observations on the dose and administration of ascorbic acid when employed beyond the range of a vitamin in human pathology, J. Appl. Nutr., 23, 61, 1971.

255. Stone, I., The Healing Factor. Vitamin C Against Disease, Grosset and Dunlap, New York, 1972.

256. Wilson, T. S., Weeks, M. M., Mukherjee, S. K., Murrell, J. S., and Andrews, C. T., A study of vitamin $C$ levels in the aged and subsequent mortality, Geront. Clin., 14, 17, 1972.

257. Spittle, C. R., Vitamin C and deep-vein thrombosis, Lancet, 2, 199, 1973.

258. Cheraskin, E. and Ringsdorf, W. M., Human vitamin $\mathrm{C}$ requirement: relation of daily intake to incidence of clinical signs and symptoms, IRCS Med. Sci., 2, 1379, 1974.

259. Taylor, T. V., Rimmer, S., Day, B., Butcher, J., and Dymock, I. W., Ascorbic acid supplementation in treatment of pressure-sores, Lancet, 2, 544, 1974.

260. Cheraskin, E., Ringsdorf, W. M., and Medford, F. H., The "ideal" daily vitamin C intake, J. Med. Assoc. State Alabama, 46, 39, 1977.

261. Bali, L. and Callaway, E., Vitamin C and migraine: a case report, N. Engl. J. Med., 299, 364, 1978.

262. Milne, J. S. and Lauder, I. J., Factors associated with mortality in older people, Age Aging, 7, 129, 1978.

263. Schorah, C. J., Newill, A., Scott, D. L., and Morgan, D. B., Clinical effects of vitamin $\mathrm{C}$ in elderly inpatients with low blood-vitamin C levels, Lancet, 1, 403, 1979.

264. Anah, C. O., Jarike, L. N., and Baig, H. A., High dose ascorbic acid in Nigerian asthmatics, Trop. Georgr. Med., 32, 132, 1980.

265. Horrobin, D. F., Sjogren's syndrome and the sicca syndrome: the role of prostaglandin E1 deficiency. Treatment with essential fatty acids and vitamin C, Med. Hypotheses, 6, 225, 1980.

266. Cathcart, R. F., Vitamin C, titrating to bowel tolerance, anascorbemia, and acute induced scurvy, Med. Hypotheses, 7, 1359, 1981.

267. Block, G., Vitamin $C$ and cancer prevention: the epidemiologic evidence, Am. J. Clin. Nutr., 53, 270S, 1991.

268. Robertson, J. M., Donner, A. P., and Trevithick, J. R., A possible role for vitamins $\mathrm{C}$ and $\mathrm{E}$ in cataract prevention, Am. J. Clin. Nutr., 53, 346S, 1991.

269. Stähelin, H. B., Gey, K. F., Eichholzer, M., Lüdin, E., Bernasconi, F., Thurneysen, J., and Brubacher, G., Plasma antioxidant vitamins and subsequent cancer mortality in the 12-year follow-up of the prospective Basel study, Am. J. Epidemiol., 133, 766, 1991.

270. Hemilä, H., Vitamin $\mathrm{C}$ and the common cold, $\mathrm{Br}$. J. Nutr., 67, 3, 1992.

271. Levine, M. and Morita, K., Ascorbic acid in endocrine systems, Vitam. Horm., 42, 1, 1985.

272. Eipper, B. A. and Mains, R. E., Peptide $\alpha$-amidation, Annu. Rev. Physiol., 50, 333, 1988.

273. Padh, H., Cellular functions of ascorbic acid, Biochem. Cell Biol., 68, 1166, 1990.

274. Subramanian, N., Histamine degradative potential of ascorbic acid: considerations and evaluations, Agents Actions, 8, 484, 1978.

275. Tannenbaum, S. R. and Wishnok, J. S., Inhibition of nitrosamine formation by ascorbic acid, Ann. $N Y$ Acad. Sci., 498, 354, 1987.

276. Zetler, G., Seidel, G., Siegers, C. P., and Iven, H., Pharmacokinetics of ascorbic acid in man, Eur. J. Clin. Pharmacol., 10, 273, 1976.

277. Hornig, D., Vuilleumier, J. P., and Hartmann, D., Absorption of large, single, oral intakes of ascorbic acid, Int. J. Vitam. Nutr. Res., 50, 309, 1980.

278. Melethil, S., Mason, W. D., and Chang, C. J., Dose-dependent absorption and excretion of vitamin C in humans, Int. J. Pharm., 31, 83, 1986.

279. Rivers, J. M., Safety of high-level vitamin C ingestion, Ann. NY Acad. Sci., 498, 445, 1987. 